\title{
Prophylactic antibiotics to prevent surgical site infection after breast cancer surgery (Review)
}

\author{
Bunn F, Jones DJ, Bell-Syer S
}

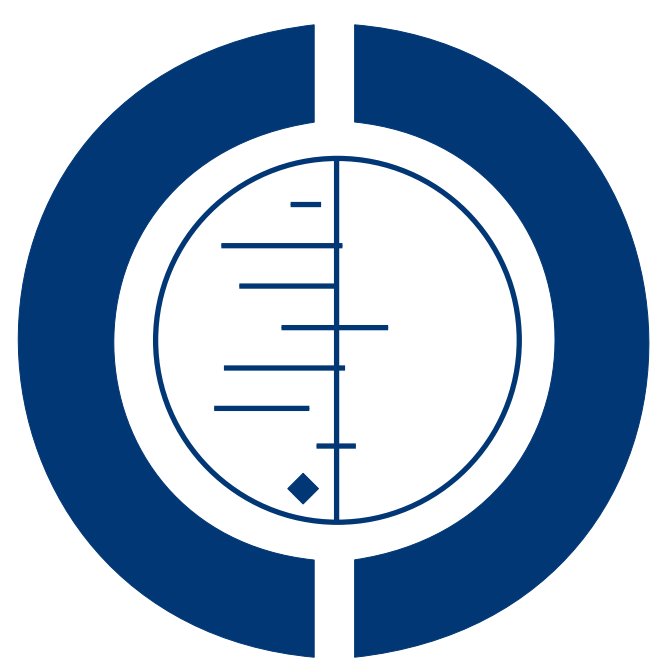

\section{THE COCHRANE COLLABORATION $^{\circledR}$}

This is a reprint of a Cochrane review, prepared and maintained by The Cochrane Collaboration and published in The Cochrane Library 2012, Issue 1

http://www.thecochranelibrary.com

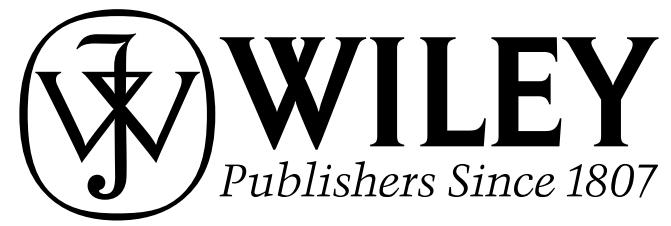

Prophylactic antibiotics to prevent surgical site infection after breast cancer surgery (Review)

Copyright (C) 2012 The Cochrane Collaboration. Published by John Wiley \& Sons, Ltd. 
TABLE OF CONTENTS

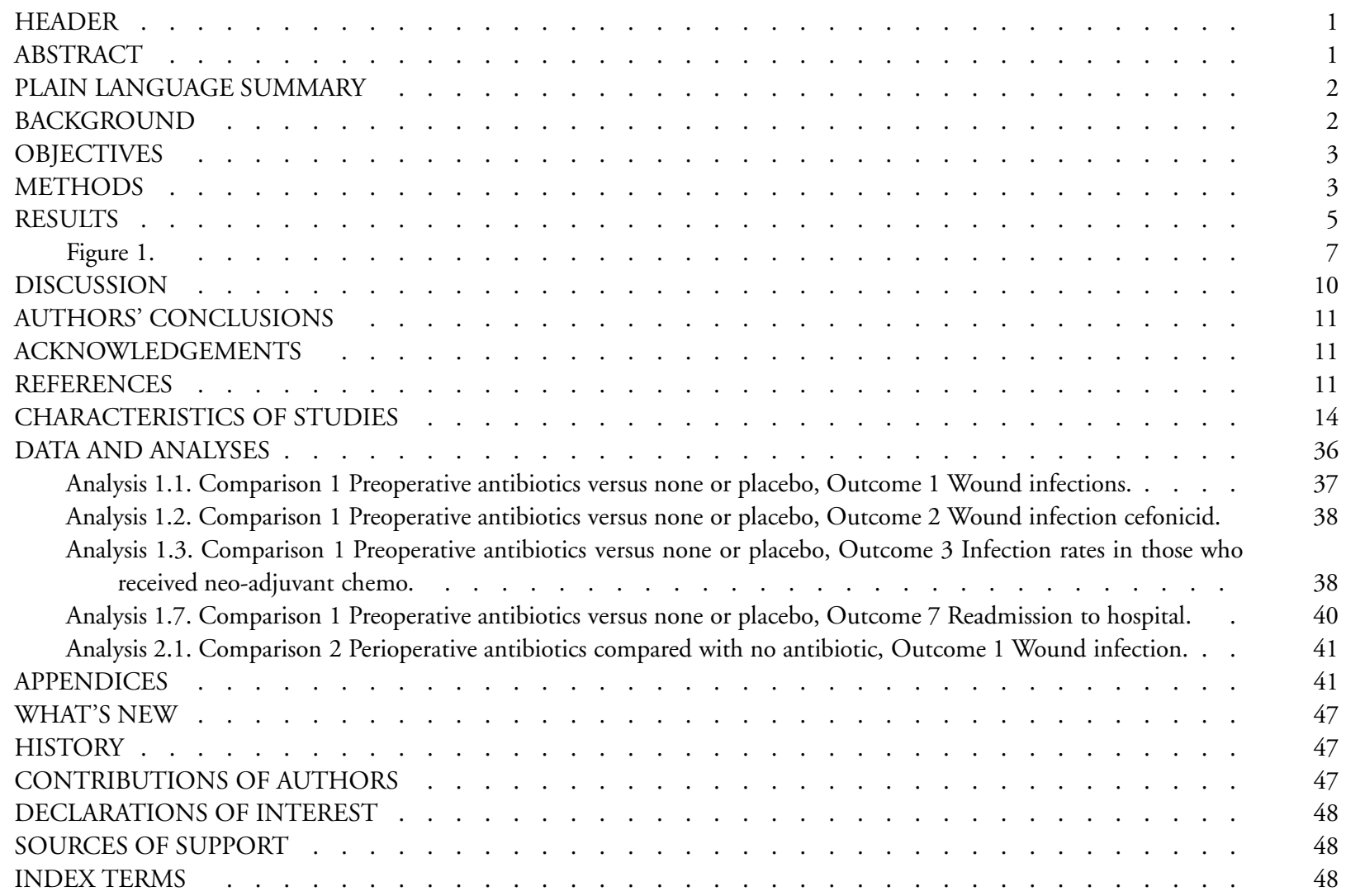




\section{Prophylactic antibiotics to prevent surgical site infection after breast cancer surgery}

Frances Bunn ${ }^{1}$, Daniel J Jones ${ }^{2}$, Sophie Bell-Syer ${ }^{3}$

${ }^{1}$ Centre for Research in Primary and Community Care, University of Hertfordshire, Hatfield, UK. ${ }^{2}$ Department of Health Sciences, University of York, York, UK. ${ }^{3}$ Medical School, Keele University, Keele, UK

Contact address: Frances Bunn, Centre for Research in Primary and Community Care, University of Hertfordshire, College Lane, Hatfield, Hertfordshire, AL10 9AB, UK. f.bunn@herts.ac.uk.

Editorial group: Cochrane Wounds Group.

Publication status and date: New search for studies and content updated (no change to conclusions), published in Issue 1, 2012.

Review content assessed as up-to-date: 31 August 2011.

Citation: Bunn F, Jones DJ, Bell-Syer S. Prophylactic antibiotics to prevent surgical site infection after breast cancer surgery. Cochrane Database of Systematic Reviews 2012, Issue 1. Art. No.: CD005360. DOI: 10.1002/14651858.CD005360.pub3.

Copyright @ 2012 The Cochrane Collaboration. Published by John Wiley \& Sons, Ltd.

A B S T R A C T

\section{Background}

Surgery has been used as part of breast cancer treatment for centuries; however any surgical procedure has the potential risk of infection. Infection rates for surgical treatment of breast cancer are documented at between 3\% and 15\%, higher than average for a clean surgical procedure. Pre- and perioperative antibiotics have been found to be useful in lowering infection rates in other surgical groups, yet there is no consensus on the use of prophylactic antibiotics for breast cancer surgery.

\section{Objectives}

To determine the effects of prophylactic (pre- or perioperative) antibiotics on the incidence of surgical site infection (SSI) after breast cancer surgery.

\section{Search methods}

For this second update we searched the Cochrane Wounds Group Specialised Register (searched 31 August 2011); the Cochrane Central Register of Controlled Trials (CENTRAL) (The Cochrane Library 2011, Issue 3); Ovid MEDLINE (2008 to August Week 3 2011); Ovid MEDLINE (In-Process \& Other Non-Indexed Citations 30 August 2011); Ovid EMBASE (1980 to 2011 Week 34); and EBSCO CINAHL (2008 to 25 August 2011). We applied no language or date restrictions.

\section{Selection criteria}

Randomised controlled trials of pre- and perioperative antibiotics for patients undergoing surgery for breast cancer were included. Primary outcomes were rates of surgical site infection (SSI) and adverse reactions.

Data collection and analysis

Two review authors independently examined the title and abstracts of all studies identified by the search strategy, then assessed study quality and extracted data from those that met the inclusion criteria. 


\section{Main results}

A total of nine studies (2260 participants) is included in the review. Eight studies evaluated preoperative antibiotic compared with no antibiotic or placebo. One study evaluated perioperative antibiotic compared with no antibiotic. Pooling of the results demonstrated that prophylactic antibiotics administered preoperatively significantly reduce the incidence of SSI for patients undergoing breast cancer surgery without reconstruction (pooled risk ratio (RR) $0.71,95 \%$ confidence interval (CI) 0.53 to 0.94 ). Analysis of the single study comparing perioperative antibiotic with no antibiotic found no statistically significant effect of antibiotics on the incidence of SSI (RR $0.11,95 \%$ CI 0.01 to 1.95). No studies presented separate data for patients who underwent reconstructive surgery at the time of removal of the breast tumour.

\section{Authors' conclusions}

Prophylactic antibiotics administered preoperatively reduce the risk of SSI in patients undergoing surgery for breast cancer. Further studies involving patients undergoing immediate breast reconstruction are needed as studies have identified this group as being at higher risk of infection than those who do not undergo immediate breast reconstruction.

\section{PLAIN LANGUAGE SUMMARY}

\section{Antibiotics to prevent surgical site infection after breast cancer surgery}

Breast cancer accounts for one in 10 of all new cancer cases diagnosed and surgical removal of the breast is a common treatment approach. An infection of the surgical wound is often a complication of surgery and taking antibiotics just before the operation significantly reduces the chances of developing an infection. The review is not able to establish which antibiotic is most appropriate. No trials were found which considered the effect of antibiotics when the operation involved immediate breast reconstruction.

\section{B A C K G R O U N D}

Breast cancer accounts for one in 10 of all new cancer cases diagnosed around the world each year (Bray 2004) and is the leading cause of cancer death in women (Pisani 1999). Surgery for removal of breast cancer has been common practice for centuries (Donegan 1995) and this is normally used as part of a multifaceted approach to care with the aim of curing the patient of their cancer in early stage tumours or prolonging life for others (NICE 2002). Surgical intervention ranges from removing the breast and associated axillary lymph nodes, to lumpectomy with or without sentinel node biopsy (Harris 2004). Whilst the risk of breast cancer for men is only $1 \%$, treatment for men is very similar to that of women (Harris 2004). As with all surgical procedures, breast cancer surgery runs the risk of complications. One such risk is postoperative surgical site infection (SSI), even though breast cancer surgery is considered a 'clean surgical procedure'. Clean surgical procedures, as defined by Haley 1985, are those which have a low risk of bacterial contamination during the surgery.Some women have immediate breast reconstruction; however this group of patients has a higher risk of SSI (Spauwen 2000).

Despite internationally recognised infection control guidelines (Mangram 1999), the incidence of SSI in those being treated for breast cancer is thought to range between 3\% (Lefebvre 2000) and $15 \%$ (Witt 2003). This is a higher incidence of infection than the $3.4 \%$ SSI rate associated with clean surgical techniques (Vazquez-Aragon 2003). A recent review (Pittet 2005) found that women who had been treated for breast cancer and who had immediate reconstruction had a SSI rate of between $0 \%$ and $53 \%$, whilst non-cancer patients undergoing the same reconstructive surgery had an average rate of $2.5 \%$. There are several factors that are documented as increasing the risk of infection for surgical patients generally. These include: patient risk factors, e.g. diabetes, obesity or smoking (Haley 1985; Mangram 1999); surgical technique, e.g. aseptic technique (Ritter 1988); and type of surgery, e.g. whether the wound is contaminated (Gruendemann 2001). In addition, surgery for breast cancer has several risk factors that make this patient group more susceptible to infection, including use of chemotherapy prior to surgery (neo-adjuvant chemotherapy); technique of diagnostic biopsy; re-operation for recurrence or to achieve better tumour margins; reconstructive surgery with implants and seroma accumulation and drainage (Morris 1988; Tran 2003). Infection may lead to significant morbidity for the patient, delay in adjuvant treatment, such as radiotherapy, and increased cost of care if the patient requires supplementary treat- 
ment due to infection (Coello 1993).

Pre- and perioperative antibiotics have been shown to reduce the risk of postoperative infection in several patient groups (the term "perioperative" refers to administration between induction of anaesthetic and the patient leaving the recovery room) (Gruendemann 2001; Majoribanks 2004; SIGN 2008a). In colorectal surgery antibiotic prophylaxis has been found to reduce long and short-term morbidity, decrease length of hospital stay and lower the overall cost of care (SIGN 2008a). However, the use of prophylactic antibiotics in preventing infection is still a controversial issue and their routine use is not common in breast cancer surgery. Some feel that a clean surgical procedure should not require prophylactic antibiotics (Sheridan 1994) and that the use of pre- or perioperative antibiotics merely masks the symptoms of infection until after the patient is discharged (Wagman 1990). In addition increased antibiotic use may lead to antibiotic resistance (PHLS 2000) and adverse effects such as clostridium difficile infection that causes gastro-intestinal problems (SIGN 2008a). In order to clarify the situation, this systematic review evaluated the effectiveness of pre- or perioperative antibiotics in reducing the incidence of postoperative infections in patients undergoing breast cancer surgery.

\section{O B J E C T I V E S}

To determine the effects of prophylactic antibiotics on SSI after breast cancer surgery.

\section{METHODS}

\section{Criteria for considering studies for this review}

\section{Types of studies}

Randomised controlled trials (RCTs) and controlled clinical trials (where patients were allocated by quasi-random methods such as alternation, case records numbers or days of the week).

\section{Types of participants}

People with breast cancer undergoing breast surgery with or without immediate re-construction as part of their treatment.

We included studies that involved mixed patient groups (i.e. cancer and non-cancer, other surgeries or breast implants not as part of cancer treatment) as long as it was possible to extract separate data for those undergoing surgery primarily to treat breast cancer.

\section{Types of interventions}

Any pre- or perioperative antibiotics used as prophylaxis where there was no known infection and where the use of antibiotics was the only systematic treatment difference between comparison groups.

We only included trials of one antibiotic compared with another if there was a control or placebo arm, as benefit from prophylactic antibiotics has not yet been established in this patient group. Definitions of key terms:

- 'Antibiotic regimen' describes the characteristics of the antibiotic treatment, i.e. type of antibiotic, route, dose, number of doses and timing of administration.

- 'Preoperative antibiotic prophylaxis' is antibiotic therapy given within 24 hours prior to surgery, solely for prophylaxis (i.e. not for an infection that is already suspected).

- 'Perioperative antibiotic prophylaxis' is antibiotic therapy administered between commencement of induction of surgery and the patient leaving the recovery room.

Comparisons of interest were as follows.

- Preoperative antibiotic compared with no antibiotic or placebo.

- Perioperative antibiotics compared with no antibiotic or placebo.

- Head to head comparisons of antibiotics.

\section{Types of outcome measures}

\section{Primary outcomes}

1. Incidence of postsurgical breast surgical site (wound) infection (SSI)*. Where possible, this should be reported as the number of participants in each group with a clinically significant infection. Research demonstrates that $98 \%$ of acute SSIs related to non-implant breast surgery occur within 28 days (Mitchell 1999). However, where there is surgical re-construction, guidelines recommend that this time is increased to one year post surgery (Mangram 1999). Therefore we included all studies that present data on acute SSI within one year of surgery.

2. Adverse reactions (e.g. anaphylaxis, gastro-intestinal or skin rash).

*Surgical site infection: ideally this will be defined using outcomes from a validated assessment tool such as ASEPSIS (Wilson 1986) which are based on CDC definitions (Mangram 1999).

\section{Secondary outcomes}

1. Death.

2. Delay in adjuvant cancer treatment because of breast wound infection.

3. Time to wound healing.

4. Time to infection. 
5. Readmission to hospital.

6. Cost of care (should be a comparison between the treatment and control group).

\section{Search methods for identification of studies}

\section{Electronic searches}

See Appendix 1 for the search strategy used for the original version of this review.

For the second update of this review we searched the following electronic databases:

- the Cochrane Wounds Group Specialised Register (searched 31 August 2011);

- the Cochrane Central Register of Controlled Trials

(CENTRAL) (The Cochrane Library 2011, Issue 3);

- Ovid MEDLINE (2008 to August Week 3 2011);

- Ovid EMBASE (1980 to 2011 Week 34);

- Ovid MEDLINE (In-Process \& Other Non-Indexed

Citations August 30, 2011);

- EBSCO CINAHL (2008 to 25 August 2011).

We used the following search strategy in the Cochrane Central Register of Controlled Trials (CENTRAL):

\#1 MeSH descriptor Surgical Wound Infection explode all trees \#2 surg* NEAR/5 infection*

\#3 surgical NEAR/5 wound*

\#4 (postoperative or post-operative) NEAR/5 infection*

\#5 MeSH descriptor Preoperative Care explode all trees

\#6 (preoperative or pre-operative) NEXT care

\#7 MeSH descriptor Perioperative Care explode all trees

\#8 (perioperative or peri-operative) NEXT care

\#9 (\#1 OR \#2 OR \#3 OR \#4 OR \#5 OR \#6 OR \#7 OR \#8)

\#10 MeSH descriptor Breast Neoplasms explode all trees with qualifier: SU

\#11 (breast NEXT cancer) NEAR/5 surg*

\#12 (breast NEXT neoplasm*) NEAR/5 surg*

\#13 (breast NEXT carcinoma*) NEAR/5 surg*

\#14 MeSH descriptor Mastectomy explode all trees

\#15 MeSH descriptor Mammaplasty explode all trees

\#16 mastectomy or mammaplasty

\#17 MeSH descriptor Breast explode all trees with qualifier: SU \#18 (\#10 OR \#11 OR \#12 OR \#13 OR \#14 OR \#15 OR \#16 OR \#17)

\#19 MeSH descriptor Anti-Bacterial Agents explode all trees

\#20 (antibiotic* or clindamycin or cefuroxime or cefuroxim or ceftazidime or ofloxacin or levofloxacin or azithromycin or sulbactam or ampicillin or mezlocillin or oxacillin or vancomycin or tobramycin or ciprofloxacin)

\#21 (\#19 OR \#20)

\#22 (\#9 AND \#18 AND \#21)
The search strategies for Ovid MEDLINE, Ovid EMBASE and EBSCO CINAHL can be found in Appendix 2, Appendix 3 and Appendix 4 respectively. We combined the MEDLINE search with the Cochrane Highly Sensitive Search Strategy for identifying randomised trials in MEDLINE: sensitivity- and precision-maximising version (2008 revision); Ovid format (Lefebvre 2011). We combined the EMBASE and CINAHL searches with the trial filters developed by the Scottish Intercollegiate Guidelines Network (SIGN) (SIGN 2008b). We applied no language or date restrictions.

\section{Searching other resources}

In addition, we screened references in all articles found by the above search strategy for further studies. We contacted experts in the field and interest groups to try and obtain access to unpublished or ongoing work. We followed up conference proceedings and grey literature that was considered to be potentially eligible for inclusion by both authors by contacting the study authors for further information.

\section{Data collection and analysis}

\section{Selection of studies}

Two review authors independently examined the title and abstract of citations identified by the search. We obtained all reports of potentially eligible trials as full-text articles and two review authors independently applied the inclusion criteria, resolving disagreements by discussion.

\section{Data extraction and management}

Two review authors independently extracted trial data using a specifically designed data extraction tool. We extracted data on study risk of bias (as defined below), antibiotic intervention (i.e. drug name, dose route, duration of treatment), setting, source of funding, length of follow-up and outcomes.

\section{Assessment of risk of bias in included studies}

For this update two review authors independently assessed each included study using the Cochrane Collaboration tool for assessing risk of bias (Higgins 2011). This tool addresses six specific domains, namely sequence generation, allocation concealment, blinding, incomplete outcome data, selective outcome reporting and other issues (e.g. extreme baseline imbalance) (see Appendix 5 for details of criteria on which the judgement was based). We assessed blinding and completeness of outcome data for each outcome separately. We completed a 'Risk of bias' table for each eligible study. We discussed any disagreement amongst all review 
authors to achieve a consensus. We presented assessment of risk of bias using a 'Risk of bias' summary figure, which presents all of the judgements in a cross-tabulation of study by entry. This display of internal validity indicates the weight the reader may give the results of each study.

\section{Assessment of heterogeneity}

We assessed heterogeneity between study results using the $\mathrm{I}^{2}$ statistic (Higgins 2003). This examined the percentage of total variation across studies due to heterogeneity rather than chance. We considered values of $\mathrm{I}^{2}$ over $75 \%$ to indicate a high level of heterogeneity and would have resulted in a random-effects model being applied or not pooling results.

\section{Data synthesis}

Where possible for each trial we calculated the risk ratio (RR) of infection and $95 \%$ confidence interval $(95 \% \mathrm{CI})$, such that a risk ratio of greater than one indicates a higher risk of infection in the first group named. We reported continuous data (i.e. number of days to infection), where possible, as mean difference (MD) with 95\% CI.

Methods of synthesising the studies were dependent on trial quality, design and heterogeneity. We explored both clinical and statistical heterogeneity. In the absence of clinical and statistical heterogeneity we applied a fixed-effect model to pool data. Where synthesis was inappropriate we have presented a narrative overview.

\section{Subgroup analysis and investigation of heterogeneity}

As patients undergoing reoperation, reconstruction with or without implants and patients receiving neo-adjuvant chemotherapy are documented as having a higher risk of infection (Tran 2003) we conducted a prespecified subgroup analysis of each of these factors where there were sufficient data available. The proposed subgroups were:

- patients undergoing immediate reconstruction without implants (i.e. TRAM flap);

- patients undergoing immediate reconstruction with implants (i.e. silicone or saline); and

- patients who have received chemotherapy (excluding hormone treatment) prior to surgery.

\section{Sensitivity analysis}

Since there is evidence that the quality of allocation concealment particularly affects the result of studies (Schulz 1995), we examined the effect of excluding studies judged to have inadequate allocation concealment in a prespecified sensitivity analysis.

\section{RE S U L T S}

\section{Description of studies}

See: Characteristics of included studies; Characteristics of excluded studies; Characteristics of studies awaiting classification.

\section{Results of the search}

We identified two further studies which met the inclusion criteria for this second update (Paajanen 2009; Yetim 2010) and excluded two studies (Esposito 2006; Sanguinetti 2009). We identified a further four abstracts which may be multiple publications of the same study and have placed these in awaiting assessment whilst we seek clarification from the study authors (Kumar 2005). In total nine studies met the inclusion criteria for this version of the review (Amland 1995; Bold 1998; Chow 2000; Gupta 2000; Hall 2006; Paajanen 2009; Platt 1990; Wagman 1990; Yetim 2010).

\section{Included studies}

\section{Participants}

Of the nine studies, six (Bold 1998; Chow 2000; Gupta 2000; Paajanen 2009; Wagman 1990; Yetim 2010) included women only, one almost entirely women (Hall 2006) and two (Amland 1995; Platt 1990) may have contained male and female breast surgery participants, although this could not be established from the data presented in the report or by contacting the authors. All of these studies included breast cancer patients as one of multiple patient groups being analysed. The studies were conducted between 1990 and 2009. Study sizes ranged between 44 (Yetim 2010) and 618 (Hall 2006). In total 2260 participants were included for meta-analysis, 1134 in treatment arms and 1126 in control arms. These studies were conducted in the hospital setting, were single-centre trials and were conducted in seven different countries. Country of origin for studies were: Australia (Hall 2006), Norway (Amland 1995), United States of America (Bold 1998; Platt 1990; Wagman 1990), Japan (Chow 2000), Finland (Paajanen 2009), Turkey (Yetim 2010) and United Kingdom (Gupta 2000). All included studies had been published.

\section{Types of surgery}

Types of participants included patients undergoing plastic surgery (Amland 1995), herniorrhaphy or breast surgery (Platt 1990), axillary lymph node dissection for breast cancer (Bold 1998) and primary, non-reconstructive surgery for breast cancer (Gupta 2000; Hall 2006; Wagman 1990). One study (Chow 2000) was designed to look at inflammatory rather than infective episodes, however discrete data on infection rates were presented and therefore the 
study was eligible for inclusion. One study looked at axillary lymph node dissection as part of breast cancer treatment (Bold 1998). One study (Paajanen 2009) looked at core needle biopsy and primary, non-reconstructive surgery for breast cancer. The three remaining studies (Gupta 2000; Wagman 1990; Yetim 2010) looked solely at breast cancer patients receiving primary, non-reconstructive surgery for breast cancer.

\section{Length of follow-up}

Length of follow-up from surgery ranged from five days (Chow 2000) to six months (Yetim 2010). One study (Gupta 2000) followed up patients between 10 and 14 days post discharge, but did not document the length of hospital stay for these patients.

\section{Source of funding}

Three studies (Amland 1995; Bold 1998; Platt 1990) stated that they were sponsored by a pharmaceutical company (Pfizer AS, Smith Kline \& Beecham and Smith Kline \& French laboratories, respectively). One study (Wagman 1990) was funded by the American Cancer Society and another (Paajanen 2009) by the Finnish cultural foundation. The source of funding was not reported in the other studies.

\section{Antibiotics used}

The antibiotics evaluated included:

- azithromycin, single dose decided according to body

weight, taken $8 \mathrm{pm}$ the night before surgery (Amland 1995).

- oral clarithromycin $(500 \mathrm{mg})$ for 10 doses (Chow 2000).

- intravenous augmentin (1.2g) (Gupta 2000).

- a single dose of intravenous flucloxacillin (2g) (Hall 2006).

- cefazolin (six doses) (Wagman 1990).

- a single dose of intravenous dicloxacillin (1g) (Paajanen 2009).

- a single dose of cefonicid (1g) (Bold 1998; Platt 1990).

- collagen plus gentamycin sulphate $(200 \mathrm{mg})$ inserted under the surgical wound prior to surgical closure (Yetim 2010).
Three studies (Bold 1998; Platt 1990; Wagman 1990) are very similar in terms of length of follow-up, choice of antibiotic and type of surgery undertaken. All studies had similar inclusion and exclusion criteria.

\section{Immediate reconstruction with or without implants}

No eligible studies evaluating prophylactic antibiotics for reconstructive surgery (with or without implants) were identified. Whilst three studies (Amland 1995; Baker 2000; Franchelli 1994) included patients undergoing reconstructive surgery, we excluded the studies following scrutiny. It was not clear that the patients had undergone surgery as part of breast cancer treatment (Amland 1995; Franchelli 1994) whilst one study was excluded because the research was addressing the needs of dental patients who have existing implants (Baker 2000).

\section{Neo-adjuvant chemotherapy}

Two studies included patients who had received neo-adjuvant chemotherapy (Bold 1998; Platt 1990).

\section{Excluded studies}

We excluded a total of 22 studies for the following reasons: two were reviews, 10 were not RCTs or quasi RCTs, one was a multiple drug comparison excluded as there was no placebo or control arm. One compared different regimens and doses, but had no control or placebo arm. We excluded one study as it could not be obtained from the British Library. Five studies did not provide discrete data for breast cancer patients and two were found to be studies focused on other types of surgery (see Characteristics of excluded studies table).

\section{Risk of bias in included studies}

See 'Risk of bias' summary figure: Figure 1. Studies were judged to be at overall unclear or high risk of bias if they were described as unclear or at high risk of bias in the majority of the domains. 
Figure I. Methodological quality summary: review authors' judgements about each methodological quality item for each included study.

\begin{tabular}{|c|c|c|c|c|c|c|c|c|}
\hline & 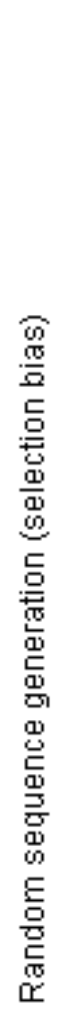 & 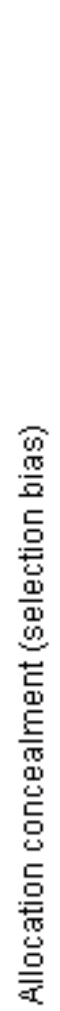 & 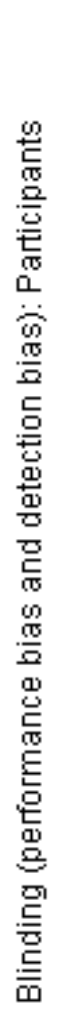 & 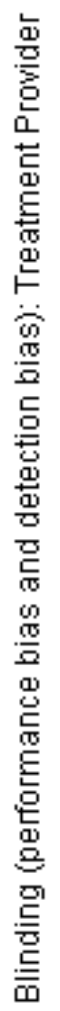 & 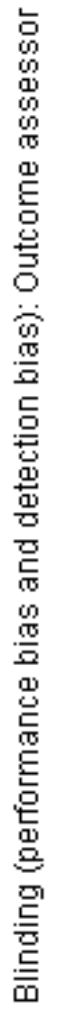 & 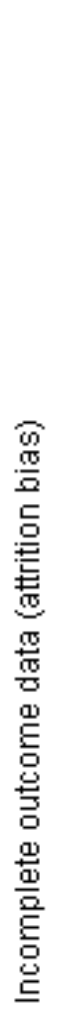 & 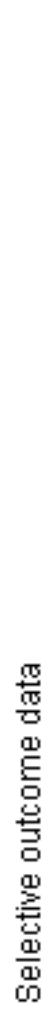 & 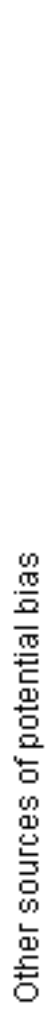 \\
\hline \multicolumn{9}{|l|}{ Amland 1995} \\
\hline Bold 1998 & 1 & + & & & ? & + & & \\
\hline Chow 2000 & + & $?$ & & & ㄱ. & 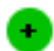 & & \\
\hline Gupta 2000 & + & 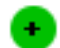 & + & & + & 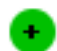 & & \\
\hline Hall 2006 & + & + & $?$ & $?$ & + & + & & \\
\hline Paajanen 2009 & $?$ & + & + & + & + & + & & \\
\hline Platt 1990 & $?$ & + & + & & & + & & \\
\hline Wagman 1990 & 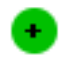 & + & + & & + & + & & \\
\hline Yetim 2010 & $?$ & $?$ & & & & $?$ & & \\
\hline
\end{tabular}




\section{Allocation}

\section{Sequence generation}

Nine studies were described as RCTs, but only six adequately generated the randomisation sequence by reporting the use of computer-generated numbers or sequences of blocks of 10 and were at low risk of bias for this domain (Amland 1995; Bold 1998; Chow 2000; Gupta 2000; Hall 2006; Wagman 1990). Three studies were classified as unclear as the authors failed to report the method by which randomisation sequence was generated (Paajanen 2009; Platt 1990; Yetim 2010).

\section{Allocation concealment}

Adequate allocation concealment was described for six studies (Bold 1998; Gupta 2000; Hall 2006; Paajanen 2009; Platt 1990; Wagman 1990) and they were therefore at low risk of bias. Three of these studies used the hospital pharmacy to generate the allocation for participants (Bold 1998; Platt 1990; Wagman 1990). One study stated that consecutive patients were allocated to group by a computer program (Chow 2000) however the method of allocation was not described and two studies used sealed opaque sequentially numbered envelopes (Gupta 2000; Hall 2006). One study reported the use of both hospital pharmacy as well as sealed, opaque, sequentially numbered envelopes (Paajanen 2009). In the remaining three studies the method of allocation concealment was not described (Amland 1995; Chow 2000; Yetim 2010) and therefore they are classified as at unclear risk of bias.

\section{Blinding}

\section{Blinding (participants and treatment providers - all outcomes)}

Adequate blinding of participants and treatment providers was clearly reported in six trials and therefore these were at low risk of bias (Amland 1995; Bold 1998; Gupta 2000; Paajanen 2009; Platt 1990; Wagman 1990). Two trials were classified as having inadequate blinding of both participants and treatment providers mainly because the control groups were not blinded as they were not given any treatment and were these two studies were at high risk of bias for this domain (Chow 2000; Yetim 2010). Whilst blinding was not specifically reported by Hall 2006 the antibiotic was administered after the induction of anaesthesia therefore it is possible that blinding was adequate but as there was no statement by the study authors we judged this to be unclear.

\section{Blinding (outcome assessors - all outcomes)}

Seven studies described adequate blinding of outcome assessors and these were at low risk of measurement bias. All antibiotic compared with placebo studies stated that the key physician was unaware of patient allocation until data collection was complete (Amland 1995; Chow 2000; Gupta 2000; Hall 2006; Paajanen 2009; Platt 1990; Wagman 1990). In one study it remained unclear if the outcome assessors were adequately blinded (Bold 1998) and in another (Yetim 2010) it was judged that the nature of the collagen implants under the wound site would unblind the outcome assessors.

\section{Incomplete outcome data}

In eight studies we judged the loss to follow-up to be low, with similar numbers of participants lost in both control and treatment groups and valid reasons given (Amland 1995; Bold 1998; Chow 2000; Gupta 2000; Hall 2006; Paajanen 2009; Platt 1990; Wagman 1990). In one study (Yetim 2010) the study was judged to be unclear for this domain because the authors stated that patients would be followed up for six months post surgery but only reported data at seven days.

We judged four studies to have undertaken an ITT analysis either because they explicitly reported this or because there were no drop outs from the study and the numbers of participants in the groups analysed at the final follow up of the study were the same as those randomised at the outset (Amland 1995; Gupta 2000; Hall 2006; Paajanen 2009). Intention-to-treat analysis was not reported in the other five studies (Bold 1998; Chow 2000; Platt 1990; Wagman 1990; Yetim 2010).

\section{Selective reporting}

The study protocols were not available but all the important outcome measures stated in the methods section are reported in the results and therefore we judged this domain to be at low risk of bias for all studies.

\section{Other potential sources of bias}

We judged six trials to be at low risk of bias for this domain because there was no imbalance in the baseline characteristics and the studies appeared free from other forms of bias (Chow 2000; Gupta 2000; Hall 2006; Paajanen 2009; Wagman 1990; Yetim 2010). In the remaining three studies (Amland 1995; Bold 1998; Platt 1990) there was some funding reported from pharmaceutical companies but it was unclear the extent of the industry involvement and we have adopted a cautious approach by judging there to be a high risk of bias. 


\section{Effects of interventions}

\section{Preoperative antibiotics compared with placebo or no antibiotic (eight trials, 2236 participants)}

Six studies (Amland 1995; Bold 1998; Gupta 2000; Paajanen 2009; Platt 1990; Wagman 1990) compared preoperative antibiotics with placebo. Two studies (Chow 2000; Hall 2006) compared preoperative antibiotics with no treatment.

\section{Incidence of postoperative wound infection}

All eight trials recorded incidence of wound infection as an outcome. Results are presented as risk ratio (RR) where the risk ratio is the risk of infection in the intervention group divided by the risk of infection in the control group. A risk ratio of less than one indicates fewer infections in the intervention group. Two studies compared cefonicid with placebo (Bold 1998; Platt 1990), one compared azithromycin with placebo (Amland 1995), one compared augmentin with placebo (Gupta 2000), one compared cefazolin with placebo (Wagman 1990), one compared flucloxacillin with no treatment (Hall 2006), one compared dicloxacillin with placebo (Paajanen 2009) and one compared clarithromycin with no treatment (Chow 2000). One study (Chow 2000) reported no infections in either group but in the remaining seven trials there were fewer infections in the groups treated with antibiotics, although this was not statistically significant in any of the individual trials (Analysis 1.1).

In addition pooling the two studies which compared cefonicid with placebo (Bold 1998; Platt 1990) showed a statistically significant reduction in infection associated with preoperative antibiotics (RR $0.56,95 \%$ confidence interval (CI) 0.33 to 0.95 ) (Analysis 1.2).

We pooled all the trials using a fixed-effect model as there was no evidence of heterogeneity $\left(\mathrm{I}^{2}=0 \%\right)$. The pooled risk ratio shows that giving preoperative antibiotics significantly reduces the risk of wound infection after breast cancer surgery (RR 0.71, 95\% CI 0.53 to 0.94 ) (Analysis 1.1 ). We carried out a sensitivity analysis to exclude one study (Chow 2000), as this study had short followup, only compared antibiotics with no antibiotic and reported inflammation rather than infection as its primary outcome. Sensitivity analysis demonstrated no effect from removing Chow from the pooled analysis.

One study (Bold 1998) documented infection rates in those who received neo-adjuvant chemotherapy; there was no statistically significant difference between the groups treated with cefonicid compared with the placebo group (RR $0.21,95 \% \mathrm{CI}, 0.01$ to 4.12 ) (Analysis 1.3). Another study provided details of the number of patients who had previously received chemotherapy (Platt 1990) but did not report separate data on infection rates for these patients.
Since there is evidence that the quality of allocation concealment influences study results (Schulz 1995) we examined the effect of excluding studies judged to have inadequate allocation concealment in a prespecified sensitivity analysis. We judged two studies (Amland 1995; Chow 2000) to have unclear allocation concealment. Removing these studies from the meta-analysis resulted in a pooled RR of 0.71 (95\% CI 0.53 to 0.95 ) which was still significantly in favour of prophylactic antibiotics.

\section{Cost of care}

One study (Bold 1998) reported the cost of care (Analysis 1.4). This did not include the cost of operation or associated stay in hospital, but calculated the cost of any additional care or medications (i.e. antibiotic prophylaxis, postoperative antibiotics or wound care). They found that the average cost per patient was USD 49.80 in the antibiotic prophylaxis group and USD 364.87 in the control group. The majority of this cost difference was accounted for in patients readmitted to hospital for wound complications.

\section{Adverse reactions to treatment}

Six studies (Bold 1998; Gupta 2000; Hall 2006; Paajanen 2009; Platt 1990; Wagman 1990) reported adverse events (please refer to other data tables for adverse effects from antibiotics under antibiotic versus none or placebo) (Analysis 1.5). Five studies reported there were no adverse events (Bold 1998; Hall 2006; Paajanen 2009; Platt 1990; Wagman 1990) and one study (Gupta 2000) reported 41 adverse events (23\%) in the treatment group and 33 $(18 \%)$ in the control group, but no details were reported on type of adverse events. Although we contacted authors for clarification about the nature of these events, they did not reply. The remaining three studies made no mention of adverse events in the study report.

\section{Death}

No studies presented information on deaths.

\section{Time to wound healing}

No studies presented information on time to wound healing.

\section{Delay in adjuvant cancer treatment caused by SSI}

No studies presented information on delays in adjuvant cancer treatments due to SSI. 


\section{Time to onset of infection}

Three studies reported time to onset of infection (Analysis 1.6), however they all provided the mean time to onset of infection and not a range and therefore we have not combined this in a metaanalysis. Two studies (Gupta 2000; Platt 1990) documented similar mean times to onset of infection: 12 and 11 days in the intervention group and 11 and 10 days in the control group respectively. Wagman 1990 documented mean time of onset of infection of 17.7 days in the intervention group and 9.6 days in the control group.

\section{Readmission to hospital}

Two studies (Bold 1998; Platt 1990) reported readmission rates following treatment. Due to heterogeneity $\left(\mathrm{I}^{2}=70.8 \%\right)$ we did not pool results. One study (Bold 1998) reported statistically significantly lower readmission rates in those treated with prophylactic antibiotics (RR 0.11, 95\% CI 0.01 to 0.88 ) (Analysis 1.7) and a shorter duration of readmission (placebo group 5.9 days, prophylaxis group 3.0 days); the other study found no reduction in readmission rates (RR 1.0, 95\% CI 0.29 to 3.42) (Analysis 1.7). As such no conclusions can be drawn on this outcome.

\section{Perioperative antibiotics compared with placebo or no antibiotic (one trial, 44 participants)}

One study (Yetim 2010) compared perioperative antibiotics with no antibiotic.

\section{Incidence of postoperative wound infection}

This small study at overall high risk of bias presented wound infection as an outcome. The study compared gentamycin-infused collagen (Gentacoll) inserted perioperatively with no antibiotic. There were no infections in the antibiotic-treated group compared with four infections in the control group. Whilst the study author stated this to be significantly better in favour of the antibiotic group this was not replicated in our analysis (RR 0.11, 95\% CI 0.01 to 1.95 ) (Analysis 2.1).

\section{Cost of care}

The study did not report the cost of care.

\section{Adverse reactions to treatment}

The study did not report any adverse reactions to treatment.

\section{Deaths}

The study did not report any information on deaths.

\section{Delay in adjuvant cancer treatment caused by SSI}

The study did not report any information on delays in adjuvant cancer treatment caused by SSI.

\section{Time to onset of infection}

The study did not report any information on the time to onset of infection.

\section{Readmission to hospital}

The study reports that two patients in the control group had to be readmitted for parenteral antibiotics as a result of wound infection. No patients in the antibiotic group were readmitted.

\section{DISCUSSION}

This review found that preoperative antibiotics significantly reduce the risk of SSI in people undergoing surgery for breast cancer when compared with placebo or no treatment. Of the seven studies that reported data on adverse events only one found an increase of events in the intervention group, however detailed information about the nature of the adverse events was not given and adverse events were generally poorly reported across the included studies. In addition data for some of the outcomes, including deaths, delays in adjuvant cancer treatments, cost and readmissions were reported by few of the included studies. We found one study that evaluated perioperative antibiotics compared with no antibiotic; this small study found that perioperative antibiotics did not significantly reduce the incidence of SSI. We found no studies evaluating antibiotics for breast reconstruction at the time of the initial surgery.

We found no other systematic reviews or meta-analyses on the effectiveness of antibiotic prophylaxis for breast cancer surgery. Two previous non-systematic reviews (D'Amico 2001; Hall 2000) did not draw any firm conclusions. Similar systematic reviews in other types of clean surgery are scarce and have produced varied results (Gillespie 2010; Sanchez-Manuel 2007).

We found only nine studies with a total of 2260 participants; not many considering the number of people affected globally by breast cancer. Whilst it is encouraging that a statistically significant result was found it is possible that the numbers are not adequate to evaluate fully the risks and benefits of antibiotic prophylaxis for breast cancer surgery. In addition, although we found some trials that included people having immediate breast reconstruction we excluded them as we were unable to obtain discrete data specifically for breast cancer patients.

Whilst all efforts were made to obtain unpublished data, all the included studies had been published, therefore there is potential 
for publication bias. Testing for publication bias was not done due to the small number of studies obtained.

Although there was no statistical heterogeneity only two studies compared the same antibiotic using the same regimen (Bold 1998; Platt 1990), therefore we were unable to make conclusions about the most effective antibiotic and regimen. Other recent research has, however, recommended that antibiotic prophylaxis should generally be administered as a single dose preoperatively in order to maximise benefit and minimise adverse effects from treatment (SIGN 2008a).

In general the included trials were at low risk of bias for the main domains of sequence generation and allocation concealment. Three studies had unclear allocation concealment (Amland 1995; Chow 2000; Yetim 2010) and excluding these studies from the analysis made little difference to the result. One study (Chow 2000) had a follow-up of only five days. As the average time to onset of infection in the other included studies ranged between 11 to 17.7 days it may have been appropriate to specify in the protocol a minimum length for follow-up. However, excluding data from this study made no difference to the overall outcomes. However, we judged one study (Yetim 2010) which compared perioperative antibiotics with no antibiotic to be at high risk of bias overall due to a failure of blinding and insufficient information given regarding selection bias.

Overall, there are sufficient data from this review to suggest that antibiotic prophylaxis reduces surgical site infections in those undergoing non-reconstructive breast cancer surgery. However further research would be required to establish the best protocols for practice.

\section{AUTHORS' CONCLUSIONS}

\section{Implications for practice}

Preoperative prophylactic antibiotics reduce the risk of a SSI in people undergoing breast cancer surgery. However, this review does not establish the most effective antibiotic regimen to use.

\section{Implications for research}

Further large, high-quality randomised controlled trials are needed to establish the most effective prophylactic antibiotic protocols. Analysis of secondary outcomes, such as adverse events, delays in adjuvant cancer treatments and costs of care, would aid the development of well considered and useful protocols and standards for practice. In addition trials need to evaluate the use of antibiotics in women undergoing immediate breast reconstruction.

\section{ACKNOWLEDGEMENTS}

The authors would like to thank referees from the Cochrane Wounds Group (Nicky Cullum, Mieke Flour, Andrew Jull, Rachel Richardson and Allyson Lipp) and from the Cochrane Breast Cancer group (Sharon Parker and Liz Lostumbo) for their comments to improve the review. Melanie Cunningham and Karen Hanscombe both contributed as authors of the original review but have not participated in any of the subsequent updates and are no longer involved.

\section{REFERENCES}

\section{References to studies included in this review}

Amland 1995 \{published data only\}

Amland PF, Andenaes K, Samdal F, Linaas E, Sandsmark $\mathrm{M}$, Abeyholm F, et al.A prospective double-blind, placebocontrolled trial of a single dose of azithromycin on postoperative wound infections in plastic surgery. Plastic and Reconstructive Surgery 1995;96(6):1378-83.

\section{Bold 1998 \{published data only\}}

Bold RJ, Mansfield PF, Berger DH, Pollock RE, Sinletary $\mathrm{SE}$, Ames FC, et al.Prospective randomised, double-blind study of prophylactic antibiotics in axillary lymph node dissection. American Journal of Surgery 1998;176(3) 239-43.

Chow 2000 \{published data only\}

Chow LW, Yuen KY, Woo PC, Wei W. Clarithromycin attenuates mastectomy-induced acute inflammatory response. Clinical and Diagnostic Laboratory Immunology 2000;7(6):925-31.
Gupta 2000 \{published data only\}

Gupta R, Sinnett D, Carpenter R, Preece PE, Royle GT. Antibiotic prophylaxis for post-operative wound infection in clean elective breast surgery. European Journal of Surgical Oncology 2000;26(4):363-6.

Hall 2006 \{published data only\}

Hall JC, Willsher PC, Hall JL. Randomized clinical trial of single-dose antibiotic prophylaxis for non-reconstructive breast surgery. British Journal of Surgery 2006;93:1342-6.

Paajanen 2009 \{published data only\} Paajanen $\mathrm{H}$, Hermunen $\mathrm{H}$. Does preoperative core needle biopsy increase surgical site infections in breast cancer surgery? Randomized study of antibiotic prophylaxis. Surgical Infections 2009;10(4):317-21.

Platt 1990 \{published data only\}

Platt R, Zaleznik DF, Hopkins CC, Dellinger EP, Karchmer AW, Bryan CS, et al.Perioperative antibiotic prophylaxis for herniopathy and breast surgery. New England Journal of Medicine 1990;322(3):153-60. 
Wagman 1990 \{published data only\}

Wagman LD, Tegtmeier B, Beatty JD, Kloth DD, Kokal WA, Riihimaki DU, et al.A prospective, randomised double-blind study of the use of antibiotics at the time of mastectomy. Surgery, Gynecology and Obstetrics 1990;170 (1):12-6.

Yetim 2010 \{published data only\}

Yetim I, Ozkan OV, Dervisoglu A, Erzurumlu K, Canbolant E. Effect of local gentamycin application on healing and wound infection in patients with modified radical mastectomy: a prospective randomised study. Journal of International Medical Research 2010;38:1442-7.

\section{References to studies excluded from this review}

\section{Baker 2000 \{published data only\}}

Baker KA. Antibiotic prophylaxis for selected implants and devices. CDA Journal 2000;28(35):620-6.

Bertin 1998 \{published data only\}

Bertin ML, Crowe J, Gordan S. Determinants of surgical site infection after breast surgery. American Journal of Infection Control 1998;26(1):61-5.

Boyd 1981 \{published data only\}

Boyd R, Burkhardt MD, Fried M, Schnur PL, Todfield JJ. Capsules, infections and intraluminal antibiotics. Plastic and Reconstructive Surgery 1981;68(1):43-7.

D'Amico 2001 \{published data only\}

D’Amico DF, Parimbelli P, Ruffolo C. Antibiotic prophylaxis in clean surgery: breast surgery and hernia repair. Journal of Chemotherapy 2001;13(1):108-11.

Erfle 2002 \{published data only\} Erfle V, Schoen A, Marquart KH, Pawlita M. [HGFStrategiefond 'Infektabwehr und Krebspaevention'. Impfstoff gegen krebs-Infektionsabwehr und Krebspraevention. Abschlussbericht. GSFForschungszentrum fuer Umwelt und Gesundhiet Neuherberg GmbH Oberschleissheim (DE)]. SIGLE. 2002

Esposito 2006 \{published data only\} Esposito S, Leone S, Noviello S, Ianniello F, Marvaso A, Cuniato V, et al.Antibiotic prophylaxis in hernia repair and breast surgery: a prospective randomised study comparing piperacillin/tazobactam versus placebo. Journal of Chemotherapy 2006;18(3):278-84.

Exener 1992 \{published data only\}

Exner K, Lang E, Borsche A, Lemperle G. Efficacy, tolerability and pharmokinetics of teicoplanin in patients undergoing breast surgery. European Journal of Surgery 1992;Suppl 567:9-12.

\section{Franchelli 1994 \{published data only\}}

Franchelli S, Leone MS, Vigna E, Rapsosio E, Cafierio F, Constantini $\mathrm{M}$, et al.Perioperative teicoplanin prophylaxis in patients undergoing breast reconstruction with the abdominal wall. A case control study. Minerva Chirurgica 1994;49(1):59-60.
Hall 2000 \{published data only\}

Hall JC, Hall JL. Antibiotic prophylaxis for patients undergoing breast surgery. Journal of Hospital Infection 2000;46:165-70

LeRoy 1991 \{published data only\}

LeRoy J, Given KS. Wound infection in breast augmentation: the role of prophylactic perioperative antibiotics. Aesthetic Plastic Surgery 1991;15:303-5.

\section{Lewis 1995 \{published data only\}}

Lewis RT, Weigand FM, Mamazza J, Lloyd-Smith W, Tataryn D. Should antibiotic prophylaxis be used routinely in clean surgical procedures: a tentative yes. Surgery 1995; 118:742-7.

Morimoto 1998 \{published data only\}

Morimoto K, Kinoshita H. Once daily use of ofloxacin for prophylaxis in breast cancer surgery. Chemotherapy 1998;44 (2):135-41.

Pennel 2004 \{published data only\}

Pennel N, Fournier C, Giard S, Lefebvres D. A prospective evaluation of antibiotic prophylaxis for breast surgery following previous chemotherapy. Bulletin du Cancer 2004; 91(5):445-8.

Platt 1992 \{published data only\}

Platt R, Zucker JR, Zaleznik DF, Hopkins CC, Dellinger EP, Karchmer AW, et al.Prophylaxis against wound infection following herniopathy or breast surgery. Journal of Infectious Diseases 1992;166(3):556-60.

Platt 1993 \{published data only\} Platt R, Zucker JR, Zaleznik DF, Hopkins CC, Dellinger EP, Karchmer AW, et al.Perioperative antibiotic prophylaxis and wound infection following breast surgery. Journal of Antimicrobial Chemotherapy 1993;31(Suppl B):43-8.

Sanguinetti 2009 \{published data only\}

Sanguinetti A, Rosato L, Cirocchi R, Barberini F, Pezzolla A, Cavallaro G, et al.Antibiotic prophylaxis in breast surgery. Preliminary results of a multicenter randomised study on 1400 cases [Antibiotico profilassi in Chirurgia Senologica Risultati preliminari di uno studio multicentrico randomizzato su 1400 casi trattati]. Annali Italiani di Chirurgia 2009;80(4):275-9.

Sasaki 1988 \{published data only\}

Sasaki F, Takada N, Hata Y, Kyunoh K, Uchino J. A study on the transfer of cefbuperazone into postoperative exudate in patients subjected to cancer mastectomy or thyroidectomy. Japanese Journal of Antibiotics 1988;466: 114-20.

Serletti 1994 \{published data only\}

Serletti JM, Davenport MS, Herrera HR, Caldwell EH. Efficacy of prophylactic antibiotics in reduction mammoplasty. Annals of Plastic Surgery 1994;33(5):476-80.

Shamilov 1991 \{published data only\} Shamilov AK, Smolianskaia AZ. The antibiotic prophylaxis of postoperative complications in breast cancer patients. Antibiotiki i Khimioterapiia 1991;36(6):43-4. 
Spicher 2003 \{published data only\}

Spicher I, Beer GM, Minder J, Ruef Ch, Szucs T, Meyer VE. Perioperative antibiotic prophylaxis at the clinic of reconstructive surgery of the university hospital Zurich [Zur umsetzung einer perioperativen antibiotikapropylaxe an der klinik fur wiederstellungschirugie des universitatsspitals Zurich]. Swiss Surgery 2003;9(1):9-14.

Sultan 1989 \{published data only\} Sultan S, Ahmed R, Mufti T, Mohammad G, Nawaz M. Use of prophylactic antibiotics in clean surgical cases - a prospective trial of various regimens. Journal of Pakistan Medical Association 1989;39(1):9-12.

Thomas 1999 \{published data only\}

Thomas R, Alivino P, Cortino GR, Accardo R, Rinaldo $\mathrm{M}$, Pizzorusso $\mathrm{M}$, et al.Long acting versus short acting cephalosporins for preoperative prophylaxis in breast surgery: a randomised double-blind trial involving 1,766 patients. Chemotherapy 1999;45(3):217-23.

\section{References to studies awaiting assessment}

\section{Baker 2005 \{published and unpublished data\}}

Baker E. Kumar S. Whetter D. Melling A. Leaper D. Does warming effect wound healing profiles following breast surgery?. European Tissue Repair Society 2005;2:68.

Kumar 2005 \{published and unpublished data\} Kumar S, Melling A, Wong PF, Whetter D, Leaper DJ. Wound infection prophylaxis in breast surgery: a randomised controlled trial comparing the efficacy of antibiotics and perioperative wound warming. British Journal of Surgery 2005;92(1):67.

Melling 2005 \{published and unpublished data\} Melling A. Kumar S. Whetter D. Baker L. Leaper D. A comparison of warming with antibiotics or both on the rate of surgical site infection after breast surgery. European Tissue Repair Society 2005;2:67.

Melling 2006 \{published and unpublished data\} Melling A. Kumar S. Whetter D. Baker E. Leaper D. Local warming may enhance the effect of prophylactic antibiotics in breast surgery. European Wound Management Association 2006; 1:88.

\section{Additional references}

\section{Bray 2004}

Bray F, McCarron P, Parkin DM. The changing global pattern of female breast cancer incidence and mortality. Breast Cancer Research 2004;6(6):229-39.

Coello 1993

Coello R, Glenister H, Fereres J, Bartlett C, Leigh D, Sedgwick J, et al.The cost of infection in surgical patients: a case control study. Journal of Hospital infection 1993;25: $239-50$.

Donegan 1995

Donegan WL, Spratt JS. Cancer of the Breast. Missouri: Elsevier Science, 1995.

\section{Gillespie 2010}

Gillespie WJ, Walenkamp G. Antibiotic prophylaxis for surgery for proximal femoral and other closed long bone fractures. Cochrane Database of Systematic Reviews 2010, Issue 3. [DOI: 10.1002/14651858.CD000244.pub2]

Gruendemann 2001

Gruendemann BJ, Magnum SS. Infection prevention in the surgical setting. London: W. B. Saunders, 2001.

Haley 1985

Haley RW, Culver DH, Mead Morgan W, White JW,

Emori GT, Hooton TM. Identifying patients at high risk of surgical wound infection. American Journal of Epidemiology 1985;121(2):206-15.

\section{Harris 2004}

Harris JR (Ed). Diseases of the Breast. Philadelphia: Lippincott Williams \& Wilkins, 2004.

\section{Higgins 2003}

Higgins JP, Thompson SG, Deeks JJ, Altman DG. Measuring inconsistency in meta-analyses. BMJ 2003;327 (7414):557-60.

\section{Higgins 2011}

Higgins JPT, Altman DG, on behalf of the Cochrane Statistical Methods Group and the Cochrane Bias Methods Group (Editors). Chapter 8: Assessing risk of bias in included studies. In: Higgins JPT, Green S (editors). Cochrane Handbook for Systematic Reviews of Interventions Version 5.1.0 [updated March 2011]. The Cochrane Collaboration, 2011. Available from www.cochrane-handbook.org.

\section{Lefebvre 2000}

Lefebvre D, Penel N, Deberles MF, Fournier C. Incidence and surgical wound infection risk factors in breast cancer surgery. Presse Medicale 2000;29(35):1927-32.

\section{Lefebvre 2011}

Lefebvre C, Manheimer E, Glanville J, on behalf of the Cochrane Information Retrieval Methods Group. Chapter 6: Searching for studies. In: Higgins JPT, Green S (editors). Cochrane Handbook for Systematic Reviews of Interventions Version 5.1.0 [updated March 2011]. The Cochrane Collaboration, 2011. Available from www.cochrane-handbook.org.

\section{Majoribanks 2004}

Majoribanks J, Jordan V, Callis K. Antibiotic prophylaxis for elective hysterectomy. Cochrane Database of Systematic Reviews 2004, Issue 1. [DOI: 10.1002/ 14651858.CD004637]

\section{Mangram 1999}

Mangram AJ, Horan TC, Pearson ML, Silver LC, Jarvis WR. Guideline for the prevention of surgical site infection. Infection Control and Hospital Epidemiology 1999;20(4): $247-78$.

Mitchell 1999

Mitchell DH, Swift G, Gilberts GL. Surgical wound infection surveillance: the importance of infections that 
develop after hospital discharge. ANZ Journal of Surgery 1999;69(2):117-20.

\section{Morris 1988}

Morris DM, Robinson K. The effect of method of biopsy and timing of mastectomy on the development of post mastectomy non sociocomial wound infection. Journal of La State Medical Society 1988;140(37):363-6.

\section{NICE 2002}

National Institute for Clinical Excellence. Guidance on cancer services: improving outcomes in breast cancer, manual update. NICE 2002.

\section{PHLS 2000}

Public Health Laboratory Service (PHLS). Antimicrobial resistance in 2000. England and Wales. http:/ /www.hpa.org.uk/web/HPAwebFile/HPAweb · C/ 11949473176962000.

\section{Pisani 1999}

Pisani P, Parkin DM, Bray F, Ferlay J. Erratum: Estimates of the worldwide mortality from 25 cancers in 1990 . Int. J. Cancer, 83, 18-29 (1999). International Journal of Cancer 1999;83(6):18-29.

Pittet 2005

Pittet B, Montandon D, Pittet D. Infection in breast implants. Lancet Infectious Diseases 2005;5(2):94-106.

\section{Ritter 1988}

Ritter MA, Marmion P. The exogenous sources and controls of microorganisms in the operating room. Orthopaedic Nursing 1988;7(4):23-8.

\section{Sanchez-Manuel 2007}

Sanchez-Manuel FJ, Seco-Gil JL. Antibiotic prophylaxis for hernia repair. Cochrane Database of Systematic Reviews 2007, Issue 3. [DOI: 10.1002/14651858.CD003769.pub3]

\section{Schulz 1995}

Schulz KF, Chalmers I, Hayes RJ, Altman DG. Empirical evidence of bias. Dimensions of methodological quality associated with estimates of treatment effects in controlled trials. JAMA 1995;273:408-12.

\section{Sheridan 1994}

Sheridan RL, Tompkins RG, Burke JF. Prophylactic antibiotics and their role in the prevention of surgical wound infection. Advances in Surgery. Year Book Medical, 1994:43-65.

\section{SIGN 2008a}

Scottish Intercollegiate Guidelines Network (SIGN). Benefits and risks of antibiotic prophylaxis. Antibiotic prophylaxis in surgery: a national clinical guideline. Available at http://www.sign.ac.uk/pdfsign104.pdf. Scottish Intercollegiate Guidelines Network, 2008:9-12.

\section{SIGN 2008b}

Scottish Intercollegiate Guidelines Network (SIGN). Search filters. http://www.sign.ac.uk/methodology/filters.html\# random (accessed 14 August 2008).

\section{Spauwen 2000}

Spauwen PHM, Wobbes T, Van Der Sluis RF. Immediate breast reconstruction: results and satisfaction. European Journal of Plastic Surgery 2000;23:211-3.

Tran 2003

Tran CL, Langer S, Brodwick-Villa G, DiFronzo LA. Does re-operation predispose to post-operative wound infection in women undergoing operation for breast cancer? . American Surgery 2003;69(10):852-6.

\section{Vazquez-Aragon 2003}

Vazquez-Aragon P, Lizan-Garcia M, Cascales-Sanchez P, Villar-Canovas MT, Garcia-Olmo D. Nosocomial infection and related risk factors in a general surgery setting: a prospective study. Journal of Infection 2003;46(1):17-22.

\section{Wilson 1986}

Wilson APR, Treasure T, Sturridge MF, Gruneberg RN. A scoring method (ASEPSIS) for postoperative wound infections for use in clinical trials of antibiotic prophylaxis. Lancet 1986;1(8476):311-3.

\section{Witt 2003}

Witt A, Yavuz D, Walchetseder C, Strohmer H, Kubista E. Preoperative core needle biopsy as an independent risk factor for wound infection after breast surgery. Obstetrics and Gynecology 2003;101(4):745-50.

* Indicates the major publication for the study 
CHARACTERISTICS OF STUDIES

Characteristics of included studies [ordered by study ID]

Amland 1995

\begin{tabular}{ll} 
Methods & $\begin{array}{l}\text { RCT: randomisation via computer-generated blocks of } 10 \\
\text { Loss to follow-up: }<20 \% \\
\text { Intention-to-treat: unclear } \\
\text { Power calculation unclear as not stated by the author } \\
\text { Reliable primary outcome: done }\end{array}$ \\
\hline Participants & $\begin{array}{l}\text { Male and female. Age } 6 \text { years or above. Admitted for plastic surgery and able to give } \\
\text { informed consent. } \\
\text { Trial exclusion criteria: intolerance to trial drug, terminal illness or immunosuppression, } \\
\text { serious underlying disease, pregnant or breast feeding, received antibiotics in the } 2 \text { weeks } \\
\text { prior to surgery, malabsorption illnesses, receiving carbamazepine or cyclosporins, renal } \\
\text { or hepatic impairment, history of mental illness } \\
\text { Total breast excision participants: } 76 \\
\text { Study included breast reconstruction and implants, which have not been included in this } \\
\text { analysis as the author could not be contacted to find out if reconstruction was secondary } \\
\text { to cancer treatment }\end{array}$ \\
\hline
\end{tabular}

Interventions

I) Azithromycin - single dose. Dose according to body weight. Dose taken $8 \mathrm{pm}$ the night before surgery $(n=42)$

C) Placebo used but no details provided $(\mathrm{n}=34)$

\begin{tabular}{ll}
\hline Outcomes & $\begin{array}{l}\text { Infection rates } \\
\text { Adverse effects }\end{array}$ \\
\hline Notes & $\begin{array}{l}\text { Length of follow-up: } 30 \text { days } \\
\text { Funding organisation not stated } \\
\text { Country of origin: Norway }\end{array}$ \\
\hline
\end{tabular}

\section{Risk of bias}

\begin{tabular}{|c|c|c|}
\hline Bias & Authors' judgement & Support for judgement \\
\hline $\begin{array}{l}\text { Random sequence generation (selection } \\
\text { bias) }\end{array}$ & Low risk & $\begin{array}{l}\text { Quote: "randomisation was performed in } \\
\text { blocks of } 10 \text { patients using a randomised } \\
\text { chart" } \\
\text { Comment: computer-generated blocks of } \\
\text { 10. Method of generating the random } \\
\text { schedule reported }\end{array}$ \\
\hline Allocation concealment (selection bias) & Unclear risk & Comment: not reported \\
\hline $\begin{array}{l}\text { Blinding (performance bias and detection } \\
\text { bias) } \\
\text { Participants }\end{array}$ & Low risk & $\begin{array}{l}\text { Comment: reported as placebo-controlled, } \\
\text { double-blind study (no further detail } \\
\text { given) }\end{array}$ \\
\hline
\end{tabular}


Amland 1995 (Continued)

\begin{tabular}{l|l|l}
$\begin{array}{l}\text { Blinding (performance bias and detection } \\
\text { bias) } \\
\text { Treatment Provider }\end{array}$ & Low risk & $\begin{array}{l}\text { Comment: reported as placebo-controlled, } \\
\text { double-blind study (no further detail } \\
\text { given) }\end{array}$ \\
\hline $\begin{array}{l}\text { Blinding (performance bias and detection } \\
\text { bias) } \\
\text { Outcome assessor }\end{array}$ & Low risk & $\begin{array}{l}\text { Quote: "Blinding was maintained until ev- } \\
\text { ery patient had completed follow-up and } \\
\text { all diagnosis of wound infection had been } \\
\text { made". } \\
\text { Comment: the wound was assessed "by } \\
\text { the physician" using "specifically designed } \\
\text { wound assessment chart". It was judged } \\
\text { that the physician undertaking the wound } \\
\text { assessment was likely blinded }\end{array}$ \\
\hline
\end{tabular}

Incomplete outcome data (attrition bias) $\quad$ Low risk $\quad$ Quote: "the inclusion of these patients in All outcomes the final analysis after the intention to treat

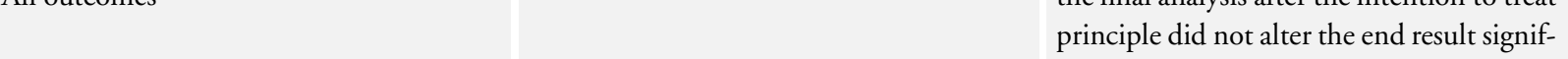
icantly."

Comment: only 1 patient was lost to follow-up (placebo group)

\begin{tabular}{|l|l|l}
\hline Selective outcome data & Low risk & $\begin{array}{l}\text { Comment: the study protocol was not } \\
\text { available, however, the results section } \\
\text { clearly reports the incidence of wound in- } \\
\text { fection using a prespecified scoring system. } \\
\text { The study states "there were } 8 \text { wound in- } \\
\text { fections in the azithromycin group and } 32 \\
\text { in the placebo group." }\end{array}$ \\
\hline Other sources of potential bias & High risk & $\begin{array}{l}\text { Comment: in the acknowledgements the } \\
\text { authors state "the present work was sup- } \\
\text { ported by Pfizer AS." This is a pharmaceu- } \\
\text { tical company. However, the study appears } \\
\text { to be free of any other source of bias }\end{array}$
\end{tabular}

\section{Bold 1998}

Methods

RCT: randomisation using computer-generated blocks

Loss to follow-up: $<20 \%$

Intention-to-treat: unclear

Power calculation: unclear, stated as under-powered

Clear definition of infection

Participants

All female; 18 years old or above undergoing axillary lymph node dissection

Excluded if: there was history of allergy to cephalosporin, aspirin use within 5 days, recent antibiotic use or infection, pregnancy or breast feeding, wound infection from surgery in the past 4 weeks, hepatic or renal impairment, diabetes, inflammatory breast cancer, concomitant isolated limb perfusion or those undergoing immediate breast re- 
Bold 1998 (Continued)

construction

Total number of patients randomised $=200$

22 excluded after randomisation

Of these, 141 were confirmed breast cancer patients

Interventions

I) Cefonicid $1 \mathrm{~g}$, intravenously 60 minutes prior to operation $(\mathrm{n}=88)$

C) Placebo used was normal saline as per antibiotic regime $(\mathrm{n}=90)$

\begin{tabular}{ll}
\hline Outcomes & $\begin{array}{l}\text { Infection rates } \\
\text { Re-hospitalisation rates } \\
\text { Cost of care } \\
\text { Adverse events }\end{array}$ \\
\hline Notes & $\begin{array}{l}\text { Length of follow-up: 4 weeks post surgery } \\
\text { Funded by SmithKline Beecham } \\
\text { Country of origin: USA }\end{array}$ \\
\hline
\end{tabular}

\section{Risk of bias}

\begin{tabular}{|c|c|c|}
\hline Bias & Authors' judgement & Support for judgement \\
\hline $\begin{array}{l}\text { Random sequence generation (selection } \\
\text { bias) }\end{array}$ & Low risk & $\begin{array}{l}\text { Quote: "Randomisation was accomplished } \\
\text { with a computer-generated block randomi- } \\
\text { sation table". } \\
\text { Comment: computer-generated blocks } \\
\text { used. Method of generating the random } \\
\text { schedule reported }\end{array}$ \\
\hline Allocation concealment (selection bias) & Low risk & $\begin{array}{l}\text { Comment: hospital pharmacy performed } \\
\text { randomisation and provided placebo or an- } \\
\text { tibiotic in identical IV bags }\end{array}$ \\
\hline $\begin{array}{l}\text { Blinding (performance bias and detection } \\
\text { bias) } \\
\text { Participants }\end{array}$ & Low risk & $\begin{array}{l}\text { Quote: "Blinding of antibiotic administra- } \\
\text { tion was accomplished through the hospi- } \\
\text { tal pharmacy." The authors go on to state } \\
\text { "[pharmacy] provided the placebo or ce- } \\
\text { fonicid in identical intravenous bags" } \\
\text { Comment: participants likely blinded }\end{array}$ \\
\hline $\begin{array}{l}\text { Blinding (performance bias and detection } \\
\text { bias) } \\
\text { Treatment Provider }\end{array}$ & Low risk & $\begin{array}{l}\text { Quote: "Blinding of antibiotic administra- } \\
\text { tion was accomplished through the hospi- } \\
\text { tal pharmacy." The authors go on to state } \\
\text { "[pharmacy] provided the placebo or ce- } \\
\text { fonicid in identical intravenous bags" } \\
\text { Comment: treatment provider likely } \\
\text { blinded }\end{array}$ \\
\hline
\end{tabular}


Bold 1998 (Continued)

\begin{tabular}{|c|c|c|}
\hline $\begin{array}{l}\text { Blinding (performance bias and detection } \\
\text { bias) } \\
\text { Outcome assessor }\end{array}$ & Unclear risk & $\begin{array}{l}\text { Quote: "patients were followed up in an } \\
\text { outpatient clinic and monitored for signs of } \\
\text { symptoms of infection." The authors go on } \\
\text { to say "a research nurse also contacted the } \\
\text { patient and referring physician for wound } \\
\text { follow up for } 4 \text { weeks after surgery" } \\
\text { Comment: no comment is made as to } \\
\text { whether the assessors remained blinded }\end{array}$ \\
\hline $\begin{array}{l}\text { Incomplete outcome data (attrition bias) } \\
\text { All outcomes }\end{array}$ & Low risk & $\begin{array}{l}\text { Quote: "Twenty-two patients were ex- } \\
\text { cluded from the analysis because of pro- } \\
\text { tocol violations". } 10 \text { were from the placebo } \\
\text { group and } 12 \text { from the treatment group. } \\
\text { This left } 90 \text { patients in the placebo group } \\
\text { and } 88 \text { patients in the cefonicid group. } \\
\text { Comment: the reasons for exclusion seem } \\
\text { valid and are unlikely to introduce bias, } \\
\text { overall the loss to follow-up was less than } \\
20 \%\end{array}$ \\
\hline
\end{tabular}

\begin{tabular}{|c|c|c|}
\hline Selective outcome data & Low risk & $\begin{array}{l}\text { Quote: in the introduction to the study } \\
\text { the authors state "the study was under- } \\
\text { taken to determine whether a single dose of } \\
\text { cephalosporin could decrease the incidence } \\
\text { of post operative wound infection". They } \\
\text { go on to state "the results would be subject } \\
\text { to a cost benefit analysis" } \\
\text { Comment: the results clearly document the } \\
\text { incidence of wound infection in table II as } \\
\text { well as a cost benefit analysis in table III }\end{array}$ \\
\hline Other sources of potential bias & High risk & $\begin{array}{l}\text { Comment: the paper states "the study was } \\
\text { sponsored in part by a grant from Smith } \\
\text { Kline \& Beecham laboratories". This is } \\
\text { a pharmaceutical company. However, the } \\
\text { study appears to be free of any other source } \\
\text { of bias }\end{array}$ \\
\hline
\end{tabular}

Chow 2000

\begin{tabular}{|c|c|}
\hline Methods & $\begin{array}{l}\text { RCT: computer-generated sequence } \\
\text { Loss to follow-up: }<20 \% \\
\text { Intention-to-treat: not done } \\
\text { Power calculation: unclear } \\
\text { Clear definition of infection: unclear. Addressed inflammation rather than infection }\end{array}$ \\
\hline Participants & $\begin{array}{l}\text { All females diagnosed with breast cancer and undergoing mastectomy } \\
\text { Total patients randomised: } 56 \text { with } 2 \text { being excluded after randomisation } \\
\text { Excluded if: pregnant, diabetic, hepatic or renal impairment, myasthenia gravis, tendency }\end{array}$ \\
\hline
\end{tabular}


Chow 2000 (Continued)

to bleeding, immunosuppression or antibiotics within the preceding 2 weeks

\begin{tabular}{ll}
\hline Interventions & $\begin{array}{l}\text { I) Clarithromycin } 500 \text { mg orally first dose commenced the day prior to surgery }(\mathrm{n}=28) \\
\text { Treatment continued twice daily for } 3 \text { days post surgery. } \\
\text { C) Control group received no placebo }(\mathrm{n}=24)\end{array}$ \\
\hline Outcomes & $\begin{array}{l}\text { Inflammatory responses } \\
\text { Infection rates } \\
\text { Flap necrosis (stated as minor in both groups) } \\
\text { Pain } \\
\text { Range of movement }\end{array}$ \\
\hline Notes & $\begin{array}{l}\text { Length of follow-up } 5 \text { days post surgery } \\
\text { Country of origin: Japan }\end{array}$ \\
\hline
\end{tabular}

Risk of bias

\begin{tabular}{|c|c|c|}
\hline Bias & Authors' judgement & Support for judgement \\
\hline $\begin{array}{l}\text { Random sequence generation (selection } \\
\text { bias) }\end{array}$ & Low risk & $\begin{array}{l}\text { Quote: "consecutive patients (except those } \\
\text { excluded) were enrolled and randomised } \\
\text { into two groups by computer". } \\
\text { Comment: randomised into } 2 \text { groups by } \\
\text { computer. Method of generating the ran- } \\
\text { dom schedule reported }\end{array}$ \\
\hline Allocation concealment (selection bias) & Unclear risk & $\begin{array}{l}\text { Comment: no further information is given } \\
\text { on the randomisation process }\end{array}$ \\
\hline $\begin{array}{l}\text { Blinding (performance bias and detection } \\
\text { bias) } \\
\text { Participants }\end{array}$ & High risk & $\begin{array}{l}\text { Quote: "Patients in the study group were } \\
\text { given oral clarithromycin. Patients in the } \\
\text { control group did not receive any clar- } \\
\text { ithromycin." } \\
\text { Comment: control group received no treat- } \\
\text { ment }\end{array}$ \\
\hline $\begin{array}{l}\text { Blinding (performance bias and detection } \\
\text { bias) } \\
\text { Treatment Provider }\end{array}$ & High risk & $\begin{array}{l}\text { Quote: "Patients in the study group were } \\
\text { given oral clarithromycin. Patients in the } \\
\text { control group did not receive any clar- } \\
\text { ithromycin." } \\
\text { Comment: control group received no treat- } \\
\text { ment }\end{array}$ \\
\hline $\begin{array}{l}\text { Blinding (performance bias and detection } \\
\text { bias) } \\
\text { Outcome assessor }\end{array}$ & Low risk & $\begin{array}{l}\text { Quote: "All surgeons and medical staff re- } \\
\text { sponsible for assessing the outcome were } \\
\text { unaware of the randomisation results be- } \\
\text { cause separate prescription sheets were } \\
\text { given for the clarithromycin prescription". } \\
\text { Comment: blinding of outcome assessor }\end{array}$ \\
\hline
\end{tabular}


Chow 2000 (Continued)

achieved

\begin{tabular}{|c|c|c|}
\hline $\begin{array}{l}\text { Incomplete outcome data (attrition bias) } \\
\text { All outcomes }\end{array}$ & Low risk & $\begin{array}{l}\text { Quote: "fifty six patients with breast can- } \\
\text { cer were recruited for the randomised trial. } \\
\text { Two patients in the control group dropped } \\
\text { out due to refusal of venepuncture." } \\
\text { Comment: the number lost to follow-up is } \\
\text { low and the reason was valid }\end{array}$ \\
\hline
\end{tabular}

$\begin{array}{ll}\text { Selective outcome data Low risk } & \text { L }\end{array}$

Comment: the study protocol was not available, however, the outcomes of this study included postoperative wound infection as well as evidence of the systemic inflammatory response syndrome. This was documented in the introduction to the study and in the outcomes. The results discuss the changes in several inflammatory markers and the results of blood culture tests. The authors state "no patient developed a wound infection"

Other sources of potential bias

Low risk

Quote: "There were no significant differences between the two groups in terms of age, area of dissection, blood loss, operation time, and the amount of parenteral fluid administered during the perioperative period".

Comment: there was no imbalance in the baseline characteristics and the study seems to be free from other forms of bias

\section{Gupta 2000}

Methods

RCT: randomisation sequence generated by computer

Loss to follow-up: $<20 \%$

Intention-to-treat: not done, 6 patients excluded from the analysis

Power calculation: done, but under-powered

Clear definition of infection: done; predefined clinical indicators

Participants

All female; 18 years of age or above

Total number: 357

44 excluded after randomisation

Exclusion criteria: known penicillin allergy, infection within 72 hours pre-surgery, pregnant, on other antibiotics or with hepatic or renal impairment

Treatment group: 177

Placebo group: 180

Diagnosis of breast cancer. Receiving mastectomy or wide local excision with or without axillary 


\section{Gupta 2000 (Continued)}

\section{Interventions}

I) Augmentin $1.2 \mathrm{~g}$ intravenous. Single dose. Given perioperatively (after induction but before first incision).

C) Placebo: normal saline as per treatment regime

\begin{tabular}{ll}
\hline Outcomes & $\begin{array}{l}\text { Infection rate } \\
\text { Adverse events } \\
\text { Time to wound healing }\end{array}$ \\
\hline Notes & $\begin{array}{l}\text { Follow-up for } 10 \text { to } 14 \text { days post discharge } \\
\text { Funding not stated } \\
\text { Country of origin: UK }\end{array}$ \\
\hline
\end{tabular}

\section{Risk of bias}

\begin{tabular}{|c|c|c|}
\hline Bias & Authors' judgement & Support for judgement \\
\hline $\begin{array}{l}\text { Random sequence generation (selection } \\
\text { bias) }\end{array}$ & Low risk & $\begin{array}{l}\text { Quote: "Patients were randomized to re- } \\
\text { ceive the antibiotic or placebo ( } 20 \mathrm{ml} 0.9 \% \\
\text { sterile saline) by reference to a computer } \\
\text { generated list". } \\
\text { Comment: computer-generated list used. } \\
\text { Method of generating the random schedule } \\
\text { reported }\end{array}$ \\
\hline
\end{tabular}

Allocation concealment (selection bias) Low risk

Blinding (performance bias and detection Low risk bias)

Participants
Quote: "The randomization list was generated by computer. The randomization codes were kept in sealed envelopes. Codes were sequentially allocated to randomized patients. Neither the patient nor any of the staff involved with this study were aware of the allocation of treatment until after the study had been completed."

Comment: sealed, opaque, sequentiallynumbered envelopes

Quote: "Patients were randomized to receive the antibiotic or placebo $(20 \mathrm{ml} 0.9 \%$ sterile saline)." The administration of antibiotic is then described "Where the study agent was administered the anaesthetist was instructed to reconstitute the antibiotic from vials of sterile powder. It was then administered to the patients as a single intravenous bolus injection through a peripherally placed 22 gauge intravenous cannula, shortly after the induction of anaesthesia". Finally the author state "neither the patient nor any of the staff involved with this study 
Gupta 2000 (Continued)

\begin{tabular}{|c|c|c|}
\hline & & $\begin{array}{l}\text { were aware of the allocation of treatment } \\
\text { until after the study had been completed". } \\
\text { Comment: the study is described as "a } \\
\text { prospective, randomised, observer blind, } \\
\text { placebo-controlled study". Participants } \\
\text { were blinded }\end{array}$ \\
\hline $\begin{array}{l}\text { Blinding (performance bias and detection } \\
\text { bias) } \\
\text { Treatment Provider }\end{array}$ & Low risk & $\begin{array}{l}\text { Quote: "Patients were randomized to re- } \\
\text { ceive the antibiotic or placebo ( } 20 \mathrm{ml} 0.9 \% \\
\text { sterile saline)." The administration of an- } \\
\text { tibiotic is then described "Where the study } \\
\text { agent was administered the anaesthetist } \\
\text { was instructed to reconstitute the antibiotic } \\
\text { from vials of sterile powder. It was then ad- } \\
\text { ministered to the patients as a single intra- } \\
\text { venous bolus injection through a peripher- } \\
\text { ally placed } 22 \text { gauge intravenous cannula, } \\
\text { shortly after the induction of anaesthesia". } \\
\text { Finally the authors state "neither the patient } \\
\text { nor any of the staff involved with this study } \\
\text { were aware of the allocation of treatment } \\
\text { until after the study had been completed". } \\
\text { Comment: healthcare providers blinded. } \\
\text { The anaesthetist was not blinded but took } \\
\text { no further part in the study }\end{array}$ \\
\hline
\end{tabular}

Blinding (performance bias and detection Low risk bias)

Outcome assessor

Quote: "At no time until the breaking of the code was the investigator made aware of whether the active agent or the placebo was administered, so making this study 'observer blind".

Comment: outcome assessors were blinded

Incomplete outcome data (attrition bias) Low risk All outcomes
Quote: "Protocol violations resulted in six patients being excluded from the intentionto-treat group". Table 1 shows that 357 patients were randomised and screened and 351 patients were "valid for efficacy analysis". The table also states that 313 patients "completed study". No information is given on these 44 patients who did not complete the study.

Comment: 3 patients were lost from each group for the efficacy analysis, but the study reports that an intention-to-treat analysis was undertaken on 351 patients

Quote: the methods section details the primary and secondary outcomes. "The pri- 
Gupta 2000 (Continued)

\begin{tabular}{|l|l}
\hline & $\begin{array}{l}\text { mary end point was the incidence of wound } \\
\text { infection. Secondary endpoints included } \\
\text { febrile morbidity, duration of post-oper- } \\
\text { ative hospital stay, delay in progressing } \\
\text { to chemotherapy radiotherapy or surgical } \\
\text { cosmesis due to wound infection and the } \\
\text { incidence of chest or urinary infection, sep- } \\
\text { ticaemia or other infections" } \\
\text { Comment: in the results the incidence of } \\
\text { wound infections are clearly shown in table } \\
\text { 6. The number of secondary endpoints is } \\
\text { also documented }\end{array}$ \\
\hline Other sources of potential bias & $\begin{array}{l}\text { Comment: the study appears to be free of } \\
\text { other sources of bias }\end{array}$ \\
\hline
\end{tabular}

Hall 2006

\begin{tabular}{ll} 
Methods & $\begin{array}{l}\text { RCT: computer-generated random numbers arranged into blocks of } 10 \\
\text { Intention-to-treat analysis: done } \\
\text { Power calculation: done } \\
\text { Reliable primary outcome: done } \\
\text { No loss to follow-up }\end{array}$ \\
\hline Participants & $\begin{array}{l}618 \text { ( } 616 \text { women and } 2 \text { men). Scheduled for non-reconstructive breast surgery. Excluded } \\
\text { if penicillin hypersensitivity, reconstructive surgery, warfarin therapy, antibiotics within } \\
72 \text { hours, phenytoin therapy or existing infection. Only } 2 \text { patients (one in each group) } \\
\text { had received preoperative chemotherapy }\end{array}$ \\
\hline Interventions & $\begin{array}{l}\text { I) Single IV dose of } 2 \text { g flucloxacillin administered over at least } 5 \text { minutes immediately } \\
\text { after the induction of general anaesthesia } \\
\text { C) No treatment }\end{array}$ \\
\hline Outcomes & $\begin{array}{l}\text { Infection rates } \\
\text { Adverse effects } \\
\text { Cellulitis } \\
\text { Wound scores }\end{array}$ \\
\hline Notes & $\begin{array}{l}\text { Follow-up: } 42 \text { days } \\
\text { Country of origin: Australia }\end{array}$ \\
\hline
\end{tabular}

\section{Risk of bias}

\begin{tabular}{|c|c|c|}
\hline Bias & Authors' judgement & Support for judgement \\
\hline $\begin{array}{l}\text { Random sequence generation (selection } \\
\text { bias) }\end{array}$ & Low risk & $\begin{array}{l}\text { Quote: "Patients were allocated to a group } \\
\text { using computer-generated random num- } \\
\text { bers arranged into blocks with a cell size of } \\
10 \text { ". }\end{array}$ \\
\hline
\end{tabular}


Hall 2006 (Continued)

\begin{tabular}{|c|c|c|}
\hline & & $\begin{array}{l}\text { Comment: computer-generated list used. } \\
\text { Method of generating the random schedule } \\
\text { reported }\end{array}$ \\
\hline Allocation concealment (selection bias) & Low risk & $\begin{array}{l}\text { Quote: "Concealment was achieved by } \\
\text { placing the group allocation into opaque, } \\
\text { serially numbered envelopes that were } \\
\text { monitored to detect breaches of the ran- } \\
\text { domisation protocol". } \\
\text { Comment: allocation concealment } \\
\text { achieved }\end{array}$ \\
\hline
\end{tabular}

Blinding (performance bias and detection Unclear risk bias)

Participants
Comment: the study had no placebo for the control group, however, the authors state "Patients in the study group received flucloxacillin $2 \mathrm{~g}$ administered intravenously, over at least $5 \mathrm{~min}$, immediately after the induction of general anaesthesia"

As the antibiotic was given after the induction of anaesthesia by an anaesthetist it may be assumed that participants were blinded but this was not reported in the study

Blinding (performance bias and detection Unclear risk bias)

Treatment Provider

Blinding (performance bias and detection Low risk

bias)

Outcome assessor

All outcomes

Low risk

Incomplete outcome data (attrition bias) Low risk
All outcomes

Selective outcome data

Low risk

Prophylactic antibiotics to prevent surgical site infection after breast cancer surgery (Review)

Comment: the study had no placebo for the control group, however, the authors state "Patients in the study group received flucloxacillin $2 \mathrm{~g}$ administered intravenously, over at least $5 \mathrm{~min}$, immediately after the induction of general anaesthesia"

As the antibiotic was given after the induction of anaesthesia by an anaesthetist it may be assumed that treatment personnel was blinded but this was not reported in the study

Quote: "All assessments [of wound infection] were performed without any knowledge of the patient's allocated group"

Comment: outcome assessors blinded

Comment: Figure 1 shows 618 patients randomised to either control or flucloxacillin. All patients were followed up at 42 days. There was no loss to follow-up

Quote: "Wound infection was the primary endpoint. It was defined as either the discharge of pus, or a serous discharge containing pathogenic organisms. Wounds were 
Hall 2006 (Continued)

\begin{tabular}{|c|c|c|}
\hline & & $\begin{array}{l}\text { also evaluated using a previously validated } \\
\text { scoring system". In the results the authors } \\
\text { clearly document the incidence of wound } \\
\text { infection "Both groups had a similar rate of } \\
\text { postoperative wound infection: ten of } 311 \\
\text { ( } 3.2 \text { per cent) in the flucloxacillin group } \\
\text { and } 14 \text { of } 307 \text { ( } 4.6 \text { per cent) in the control } \\
\text { group." } \\
\text { Comment: the study protocol was not } \\
\text { available but the important outcome mea- } \\
\text { sures stated in the methods section are re- } \\
\text { ported in the results }\end{array}$ \\
\hline Other sources of potential bias & Low risk & $\begin{array}{l}\text { Comment: the study appears to be free of } \\
\text { other sources of bias }\end{array}$ \\
\hline
\end{tabular}

Pajanen 2009

$\begin{array}{ll}\text { Methods } & \text { RCT: method of randomisation not reported } \\ \text { No loss to follow-up } \\ \text { Intention-to-treat analysis: done as all the participants were analysed in the groups to } \\ \text { which they were randomised } \\ \text { Power calculation: unclear as not stated by the author } \\ \text { Reliable primary outcome: done } \\ \text { Clear definition of infection: done }\end{array}$

Participants

All females patients undergoing non-reconstructive breast cancer surgery between years 2004 and 2007 were included

Total number: 292

Exclusion criteria patients with lack of consent, penicillin hypersensitivity, logistic failure

Treatment group: 144

Control group: 148

Diagnosis of breast cancer. Confirmed preoperatively by mammographic stereotactic or ultrasound-guided core needle biopsy

Interventions

I) Intravenous $1 \mathrm{~g}$ of dicloxacillin in a $100 \mathrm{ml}$ bottle. Single dose 30 minutes before surgery.

C) Placebo infusion of $100 \mathrm{ml}$ of saline

\begin{tabular}{ll}
\hline Outcomes & Infection rates \\
\hline Notes & Follow-up: 30 days \\
& Country of origin: Finland \\
\hline
\end{tabular}

\section{Risk of bias}

Bias

Authors' judgement

Support for judgement 
Paajanen 2009 (Continued)

\begin{tabular}{|c|c|c|}
\hline $\begin{array}{l}\text { Random sequence generation (selection } \\
\text { bias) }\end{array}$ & Unclear risk & $\begin{array}{l}\text { Quote: "The patients were randomised to } \\
\text { receive either an intravenous single dose of } \\
1 \mathrm{~g} \text { of dicloxacillin in a } 100 \mathrm{ml} \text { or a placebo } \\
\text { infusion of } 100 \mathrm{ml} \text { of saline } 30 \mathrm{~min} \text { prior } \\
\text { to surgery." } \\
\text { Comment: method of generating the ran- } \\
\text { dom schedule not reported }\end{array}$ \\
\hline Allocation concealment (selection bias) & Low risk & $\begin{array}{l}\text { Quote: "The hospital pharmacy generated } \\
\text { allocation using sealed opaque sequentially } \\
\text { numbered envelopes." } \\
\text { Comment: allocation concealed using } \\
\text { sealed opaque sequentially numbered en- } \\
\text { velopes }\end{array}$ \\
\hline
\end{tabular}

Blinding (performance bias and detection Low risk bias)

Participants

Quote: “The research group including the operating surgeon, research nurses, other medical staff, and study participants, were blinded to the participant's allocation." Comment: participants were blinded adequately

Blinding (performance bias and detection Low risk bias)

Treatment Provider

Quote: "The research group including the operating surgeon, research nurses, other medical staff, and study participants, were blinded to the participant's allocation."

Comment: healthcare providers were blinded adequately

Blinding (performance bias and detection Low risk bias)

Outcome assessor

Quote: “All assessments were performed without knowledge of the patient's assigned group."

Comment: outcome assessors were blinded adequately

Incomplete outcome data (attrition bias) Low risk All outcomes

Selective outcome data
Low risk

Comment: there was no loss to follow-up. Table 3 depicts that all the randomised participants were analysed in the group to which they were allocated

Quote: the authors state that SSI was the primary endpoint. A clear definition of infection is documented. The results state "The rate of postoperative SSI was 5.6\% $(8 / 144)$ in the dicloxacillin group and 8. $8 \%(13 / 148)$ in the placebo group."

Comment: the study protocol was not available but the important outcome mea- 
Paajanen 2009 (Continued)

\begin{tabular}{|c|c|c|}
\hline & & $\begin{array}{l}\text { sures stated in the methods section are re- } \\
\text { ported in the results }\end{array}$ \\
\hline Other sources of potential bias & Low risk & $\begin{array}{l}\text { Quote: "The patient characteristics and } \\
\text { risk factors for SSI were similar in the an- } \\
\text { tibiotic prophylaxis and placebo groups." } \\
\text { Comment: there was no imbalance in the } \\
\text { baseline characteristics and the study seems } \\
\text { to be free from other forms of bias }\end{array}$ \\
\hline
\end{tabular}

\section{Platt 1990}

$\begin{array}{ll}\text { Methods } & \text { RCT; randomisation via blocks of } 10 \\ \text { Loss to follow-up: }<20 \% \\ \text { Intention-to-treat: unclear } \\ \text { Power calculation: adequate for the study as a whole, but may be under-powered for the } \\ \text { breast group } \\ \text { Clear definition of infection: done }\end{array}$

Participants

Included male and female patients aged 18 or above having mastectomy, lumpectomy, excisional breast biopsy, axillary node clearance or reduction mammoplasty. Included are those who speak English, lived within 35 miles of the hospital, have no recognised infection at the time of surgery, recent antibiotic use or known allergy to beta-lactam antibiotics.

Total number of participants: 606

18 years old or over

Interventions
$\begin{aligned} & \text { I) Cefonicid } 1 \mathrm{~g} \text { intravenous. Within } 90 \text { minutes pre-surgery }(\mathrm{n}=303) \text {. Dose regime: } \\ & \text { single dose. } \\ & \text { C) Placebo was a mixture of glycerin, mannitol and riboflavin given as per the treatment } \\ & \text { regime }\end{aligned}$

\begin{tabular}{l|l} 
Outcomes & Infection rate \\
Adverse reaction to treatment & Time to onset of infection \\
\hline Associated morbidity from wound infection \\
Economic evaluation \\
Other infective episodes
\end{tabular}

\begin{tabular}{ll}
\hline Notes & Length of follow-up: 4 to 6 weeks \\
& Sponsored by Smith, Kline and French Laboratories \\
Country of origin: USA
\end{tabular}

\section{Risk of bias}

Bias
Authors' judgement
Support for judgement 
Platt 1990 (Continued)

\begin{tabular}{|c|c|c|}
\hline $\begin{array}{l}\text { Random sequence generation (selection } \\
\text { bias) }\end{array}$ & Unclear risk & $\begin{array}{l}\text { Quote: "patients were randomly assigned } \\
\text { separately in blocks of } 10 \text { to receive cefoni- } \\
\text { cid or placebo." } \\
\text { Comment: method of generating the ran- } \\
\text { dom schedule not reported }\end{array}$ \\
\hline Allocation concealment (selection bias) & Low risk & $\begin{array}{l}\text { Quote: "treatment codes were not known } \\
\text { by anyone at the participating centres un- } \\
\text { less the sealed opaque label attached to each } \\
\text { vial was opened." They go on to state "in- } \\
\text { vestigators were required to return these la- } \\
\text { bels intact." } \\
\text { Comment: allocation concealment } \\
\text { achieved }\end{array}$ \\
\hline
\end{tabular}

Blinding (performance bias and detection Low risk bias)

Participants
Quote: study described as a "Randomised, double-blind trial". "Cefonicid and placebo were supplied in identical numbered vials. The authors state "treatment codes were not known by anyone at the participating centres unless the sealed opaque label attached to each vial was opened." They go on to state "investigators were required to return these labels intact". Comment: participants were blinded adequately

Blinding (performance bias and detection Low risk bias)

Treatment Provider bias)

Outcome assessor

Prophylactic antibiotics to prevent surgical site infection after breast cancer surgery (Review)

Quote: study described as a "Randomised, double-blind trial". "Cefonicid and placebo were supplied in identical numbered vials. The authors state "treatment codes were not known by anyone at the participating centres unless the sealed opaque label attached to each vial was opened." They go on to state "investigators were required to return these labels intact. ".

Comment: treatment providers were blinded adequately

Quote: "drug assignments were not known during any follow up evaluations, including non scheduled visits for suspected wound infection." They repeat this in the surveillance of wound infection paragraph "all investigators were unaware of the treatment codes until the last evaluation was completed."

Comment: automated data processing and 
Platt 1990 (Continued)

\begin{tabular}{l|l}
\hline $\begin{array}{l}\text { Incomplete outcome data (attrition bias) } \\
\text { All outcomes }\end{array}$ & $\begin{array}{l}\text { analyses in laboratory. Outcome assessor } \\
\text { blinded }\end{array}$ \\
\hline Low risk & $\begin{array}{l}\text { Comment: table } 1 \text { documents numbers of } \\
\text { and reasons for exclusion of patients from } \\
\text { analysis after randomisation. } 50 \text { patients } \\
\text { from the treatment group and 51 from the } \\
\text { control group were excluded. Similar rea- } \\
\text { sons for exclusion were documented for } \\
\text { both groups. No separate exclusion data are } \\
\text { given for the breast cancer patients }\end{array}$ \\
\hline Oelective outcome data & $\begin{array}{l}\text { Overall the loss to follow-up was less than } \\
\text { 20\% and therefore judged to be adequate }\end{array}$ \\
\hline Low risk & $\begin{array}{l}\text { Comment: the study protocol was not } \\
\text { available, however, the incidence of wound } \\
\text { infection was the primary outcome mea- } \\
\text { sure. The authors document the definition } \\
\text { of a wound infection clearly. The results are } \\
\text { displayed in table 4. They are separated for } \\
\text { breast surgery verses hernia surgery }\end{array}$ \\
\hline
\end{tabular}

\section{Wagman 1990}

\begin{tabular}{|c|c|}
\hline Methods & $\begin{array}{l}\text { RCT: random numbers table generated by dept of biostatistics } \\
\text { Loss to follow-up: }<20 \% \\
\text { Intention-to-treat: unclear } \\
\text { Power calculation: unclear } \\
\text { Clear definition of infection: done; predefined clinical indicators }\end{array}$ \\
\hline Participants & $\begin{array}{l}\text { All breast cancer surgery except re-construction } \\
\text { Excluded were those with a history of allergy to the study antibiotic or receiving other } \\
\text { antibiotics } \\
\text { Total number of participants: } 118\end{array}$ \\
\hline Interventions & $\begin{array}{l}\text { I) Cefazolin } 25 \text { mg per kg. Intravenous. First dose within } 30 \text { minutes pre-surgery. Dose } \\
\text { regime: } 6 \text { doses at } 6 \text {-hour intervals }(n=59) \text {. } \\
\text { C) Placebo: normal saline bolus as per the treatment regime }(n=59)\end{array}$ \\
\hline Outcomes & $\begin{array}{l}\text { Infection rates } \\
\text { Adverse events } \\
\text { Time to onset of infection }\end{array}$ \\
\hline
\end{tabular}




\begin{tabular}{l|l} 
& $\begin{array}{l}\text { Affect of length of surgery } \\
\text { Affect of pre-surgery biopsy }\end{array}$ \\
\hline Notes & $\begin{array}{l}\text { Length of follow-up: } 30 \text { days postoperative } \\
\text { Country of origin: USA } \\
\text { Sponsored by the American society career development award }\end{array}$ \\
\hline
\end{tabular}

\section{Risk of bias}

\begin{tabular}{|c|c|c|}
\hline Bias & Authors' judgement & Support for judgement \\
\hline $\begin{array}{l}\text { Random sequence generation (selection } \\
\text { bias) }\end{array}$ & Low risk & $\begin{array}{l}\text { Quote: "Randomisation was performed in } \\
\text { the Pharmacy using a table of random } \\
\text { numbers generated by the Department of } \\
\text { Biostatistics". } \\
\text { Comment: random number tables used. } \\
\text { Method of generating the random schedule } \\
\text { reported }\end{array}$ \\
\hline Allocation concealment (selection bias) & Low risk & $\begin{array}{l}\text { Quote: "Randomisation was performed in } \\
\text { the Pharmacy using a table of random } \\
\text { numbers generated by the Department of } \\
\text { Biostatistics". } \\
\text { Comment: central allocation, i.e. phar- } \\
\text { macy-controlled }\end{array}$ \\
\hline
\end{tabular}

Blinding (performance bias and detection Low risk bias)

Participants

Blinding (performance bias and detection Low risk bias)

Treatment Provider

\begin{aligned} Co \\ \hline\end{aligned}

Blinding (performance bias and detection Low risk bias)

Outcome assessor

Incomplete outcome data (attrition bias) Low risk All outcomes
Quote: "The patient, surgeon and Infection Control office had no knowledge of the patient assignments".

Comment: blinding of participants done

Quote: "The patient, surgeon and Infection Control office had no knowledge of the patient assignments".

Comment: blinding of treatment providers done

Quote: "The patient, surgeon and Infection Control office had no knowledge of the patient assignments. The code was broken after initial data evaluation".

Comment: blinding of outcome assessors done

Quote: "Nine patients were excluded from the study after randomisation (one patient did not undergo surgical treatment, one underwent biopsy only, five patients failed to receive a complete course of antibiotics 


\begin{tabular}{|c|c|c|}
\hline & & $\begin{array}{l}\text { and two had antibiotics for another reason" } \\
\text { Comment: the number lost to follow-up is } \\
\text { low and the reasons were valid }\end{array}$ \\
\hline Selective outcome data & Low risk & $\begin{array}{l}\text { Comment: the study protocol was not } \\
\text { available but the important outcome mea- } \\
\text { sures stated in the methods section are re- } \\
\text { ported in the results }\end{array}$ \\
\hline Other sources of potential bias & Low risk & $\begin{array}{l}\text { Comment: the study appears to be free of } \\
\text { other sources of bias }\end{array}$ \\
\hline
\end{tabular}

\section{Yetim 2010}

$\begin{array}{ll}\text { Methods } & \text { RCT: patients were randomly allocated into } 1 \text { of } 2 \text { groups } \\ \text { No loss to follow-up } & \text { Intention-to-treat analysis: done as all the participants were analysed in the groups to } \\ \text { which they were randomised } \\ \text { Power calculation: not done } \\ \text { Reliable primary outcome: done }\end{array}$

\begin{tabular}{ll} 
Participants & All female patients who were diagnosed with breast cancer and underwent modified \\
radical mastectomy with axillary dissection between June 2006 and June 2009 were \\
included \\
Exclusion criteria: patients with inflammatory breast cancer who had neoadjuvant ra- \\
diotherapy, chronic diseases, e.g. diabetes, immune suppression, were excluded \\
Treatment group: 22 \\
Control group: 22 \\
\hline
\end{tabular}

Interventions

I) Gentacoll applied to the axillary area and under the flap before closure of the surgical wound. Two pieces of Gentacoll were used in each area. Gentacoll is $10 \mathrm{~cm} \mathrm{x} 10 \mathrm{~cm} \mathrm{x}$ $0.5 \mathrm{~cm}$ collagen from equine tendons with $200 \mathrm{mg}$ gentamycin sulphate

C) No Gentacoll

\begin{tabular}{ll}
\hline Outcomes & Wound infection \\
& $\begin{array}{l}\text { Seroma formation } \\
\text { Drain removal time } \\
\text { Total drainage volumes } \\
\text { Duration of hospital stay }\end{array}$ \\
\hline Notes & Length of follow-up: 6 months \\
& Country of origin: Turkey \\
\hline
\end{tabular}

\section{Risk of bias}

Bias
Authors' judgement
Support for judgement 
Yetim 2010 (Continued)

\begin{tabular}{|c|c|c|}
\hline $\begin{array}{l}\text { Random sequence generation (selection } \\
\text { bias) }\end{array}$ & Unclear risk & $\begin{array}{l}\text { Quote: "patients were randomly allocated } \\
\text { in to one of two groups" } \\
\text { Comment: no further information regard- } \\
\text { ing randomisation is given }\end{array}$ \\
\hline Allocation concealment (selection bias) & Unclear risk & $\begin{array}{l}\text { Comment: no information is given regard- } \\
\text { ing the concealment of randomisation }\end{array}$ \\
\hline
\end{tabular}

Blinding (performance bias and detection High risk bias)

Participants

Quote: “Group I underwent modified radical mastectomy during which Gentacoll was applied to the axiliary area and under the flap area of the breast before closure of the surgical wound. Two pieces of Gentacoll were used for each area, each comprising $10 \times 10 \times 0.5 \mathrm{~cm}$ collagen plus gentamycin sulphate $(200 \mathrm{mg})$. Group II underwent modified radical mastectomy without the application of Gentacoll."

Comment: it is not clear whether the participants were blinded in the study, however, they may be aware of four $10 \times 10 \mathrm{x}$ $0.5 \mathrm{~cm}$ collagen placed under the skin and were therefore unable to be blinded

Blinding (performance bias and detection High risk bias)

Treatment Provider

Quote: "Group I underwent modified radical mastectomy during which Gentacoll was applied to the axiliary area and under the flap area of the breast before closure of the surgical wound. Two pieces of Gentacoll were used for each area, each comprising $10 \times 10 \times 0.5 \mathrm{~cm}$ collagen plus gentamycin sulphate $(200 \mathrm{mg})$. Group II underwent modified radical mastectomy without the application of Gentacoll."

Comment: as the surgeons were responsible for applying the Gentacoll they could not be blinded in the study

Blinding (performance bias and detection High risk bias)

Outcome assessor
Quote: "patients were followed up 7 days after discharge from hospital and at 1, 3 and 6 months after surgery"

Comment: no information is given as to who performed the follow-up and whether or not they were blinded. At follow-up would infection and seroma formation was assessed as well as drain information and duration of hospital stay. It could be considered that the healthcare professional as- 
Yetim 2010 (Continued)

\begin{tabular}{|l|l|l}
\hline & $\begin{array}{l}\text { sessing for wound infection would be able } \\
\text { to see if collagen implants had been inserted }\end{array}$ \\
\hline $\begin{array}{l}\text { Incomplete outcome data (attrition bias) } \\
\text { All outcomes }\end{array}$ & Unclear risk & $\begin{array}{l}\text { Comment: there was no loss to follow-up } \\
\text { documented in the study. 44 patients were } \\
\text { enrolled and randomised and the results ta- } \\
\text { bles given follow-up data for all } 44 \text { partic- } \\
\text { ipants. However, the authors state that pa- } \\
\text { tients would be followed up for } 6 \text { months } \\
\text { post surgery, the only information given in } \\
\text { the paper is for the first 7 days }\end{array}$ \\
\hline Selective outcome data & Low risk & $\begin{array}{l}\text { Comment: } \\
\text { study protocol was not available, however, } \\
\text { wound infection, seroma formation, drain } \\
\text { removal time, total drainage volumes and } \\
\text { duration of hospital stay were recorded and } \\
\text { displayed in results tables } 2 \text { and } 3\end{array}$ \\
\hline
\end{tabular}

C: control

I: intervention

IV: intravenous

RCT: randomised controlled trial

Characteristics of excluded studies [ordered by study ID]

\begin{tabular}{ll}
\hline Study & Reason for exclusion \\
\hline Baker 2000 & $\begin{array}{l}\text { This study was from the perspective of dentists managing risk in patients undergoing dental work who are at risk } \\
\text { of remote infection due to implants, not infection risk as an acute surgical complication }\end{array}$ \\
\hline Bertin 1998 & Not a RCT or quasi-RCT \\
\hline Boyd 1981 & Not a RCT, retrospective analysis \\
\hline D'Amico 2001 & Review \\
\hline Erfle 2002 & Not a RCT or quasi-RCT \\
\hline
\end{tabular}

Esposito 2006 Study includes hernia repair and breast cancer surgery. Unable to separate data for breast patients 
(Continued)

\begin{tabular}{|c|c|}
\hline Exener 1992 & Unable to obtain through the British Library \\
\hline Franchelli 1994 & $\begin{array}{l}\text { Although the data were on reconstructive surgery, the paper did not state being secondary to breast cancer } \\
\text { treatment. It also did not state whether the surgery was immediate or delayed reconstruction }\end{array}$ \\
\hline Hall 2000 & Review \\
\hline LeRoy 1991 & Excluded as retrospective analysis \\
\hline Lewis 1995 & Excluded as unable to obtain separate data for breast patients despite writing to the author \\
\hline Morimoto 1998 & Excluded as this study was comparing antibiotic dose and regime rather than antibiotic versus placebo/none \\
\hline Pennel 2004 & Not a RCT or quasi-RCT \\
\hline Platt 1992 & Not a RCT or quasi-RCT \\
\hline Platt 1993 & $\begin{array}{l}\text { This is a meta-analysis of Platt (1990) and Platt (1992). Platt } 1992 \text { was not a RCT and Platt } 1990 \text { has been used } \\
\text { within this systematic review. }\end{array}$ \\
\hline Sanguinetti 2009 & Removal of benign lesions included in study. No separate data was obtainable for breast cancer patients \\
\hline Sasaki 1988 & Excluded as not a RCT following translation. No comparison made \\
\hline Serletti 1994 & Addressed reduction mammoplasty. Surgery not cancer-related. \\
\hline Shamilov 1991 & Not a RCT or quasi-RCT \\
\hline Spicher 2003 & $\begin{array}{l}\text { Found not to be a RCT following translation. The article analyses the authors experience of implementing } \\
\text { guidelines for using antibiotics with patients undergoing reconstructive surgery }\end{array}$ \\
\hline Sultan 1989 & No separate data were obtainable for breast patients \\
\hline Thomas 1999 & Addresses long-acting versus short-acting antibiotic comparison rather than antibiotic versus none or placebo \\
\hline
\end{tabular}

RCT: randomised controlled trial 


\section{Characteristics of studies awaiting assessment [ordered by study ID]}

\section{Baker 2005}

\begin{tabular}{l} 
Methods \\
\hline Participants \\
\hline Interventions \\
\hline Outcomes \\
\hline Notes $\quad$ Awaiting clarification of study details from the author
\end{tabular}

\section{Kumar 2005}

Methods

Participants

Interventions

Outcomes

Notes Awaiting clarification of study details from the author

Melling 2005

Methods

Participants

Interventions

Outcomes

Notes Awaiting clarification of study details from the author

Melling 2006

Methods

Participants

Interventions

Interventions

Outcomes

Notes Awaiting clarification of study details from the author


DATA AND ANALYSES

Comparison 1. Preoperative antibiotics versus none or placebo

\begin{tabular}{|c|c|c|c|c|}
\hline Outcome or subgroup title & $\begin{array}{l}\text { No. of } \\
\text { studies }\end{array}$ & $\begin{array}{c}\text { No. of } \\
\text { participants }\end{array}$ & Statistical method & Effect size \\
\hline 1 Wound infections & 8 & 2236 & Risk Ratio (M-H, Fixed, 95\% CI) & $0.71[0.53,0.94]$ \\
\hline $\begin{array}{l}\text { 1.1 Preoperative antibiotic } \\
\text { versus placebo }\end{array}$ & 6 & 1566 & Risk Ratio (M-H, Fixed, 95\% CI) & $0.71[0.52,0.96]$ \\
\hline $\begin{array}{l}1.2 \text { Preoperative antibiotic } \\
\text { versus none }\end{array}$ & 2 & 670 & Risk Ratio (M-H, Fixed, 95\% CI) & $0.71[0.32,1.56$ \\
\hline 2 Wound infection cefonicid & 2 & 747 & Risk Ratio (M-H, Fixed, 95\% CI) & $0.56[0.33,0.95]$ \\
\hline $\begin{array}{l}3 \text { Infection rates in those who } \\
\text { received neo-adjuvant chemo }\end{array}$ & 1 & 47 & Risk Ratio (M-H, Fixed, 95\% CI) & $0.21[0.01,4.12]$ \\
\hline 4 Cost of care & & & Other data & No numeric data \\
\hline 5 Adverse effects from antibiotics & & & Other data & No numeric data \\
\hline $\begin{array}{l}5.1 \text { Preoperative antibiotics } \\
\text { versus placebo }\end{array}$ & & & Other data & No numeric data \\
\hline $\begin{array}{l}5.2 \text { Preoperative antibiotics } \\
\text { versus none }\end{array}$ & & & Other data & No numeric data \\
\hline 6 Time to onset of infection & & & Other data & No numeric data \\
\hline $\begin{array}{l}\text { 6.1 Preoperative antibiotic } \\
\text { versus placebo }\end{array}$ & & & Other data & No numeric data \\
\hline 7 Readmission to hospital & 2 & & Risk Ratio (M-H, Random, 95\% CI) & Subtotals only \\
\hline $\begin{array}{l}\text { 7.1 Preoperative antibiotics } \\
\text { versus placebo }\end{array}$ & 2 & 784 & Risk Ratio (M-H, Random, 95\% CI) & $0.39[0.04,3.49]$ \\
\hline
\end{tabular}

Comparison 2. Perioperative antibiotics compared with no antibiotic

\begin{tabular}{lcccc} 
Outcome or subgroup title & $\begin{array}{c}\text { No. of } \\
\text { studies }\end{array}$ & $\begin{array}{c}\text { No. of } \\
\text { participants }\end{array}$ & Statistical method & Effect size \\
\hline 1 Wound infection & 1 & & Risk Ratio (M-H, Fixed, 95\% CI) & Totals not selected \\
\hline
\end{tabular}


Analysis I.I. Comparison I Preoperative antibiotics versus none or placebo, Outcome I Wound infections.

Review: Prophylactic antibiotics to prevent surgical site infection after breast cancer surgery

Comparison: I Preoperative antibiotics versus none or placebo

Outcome: I Wound infections

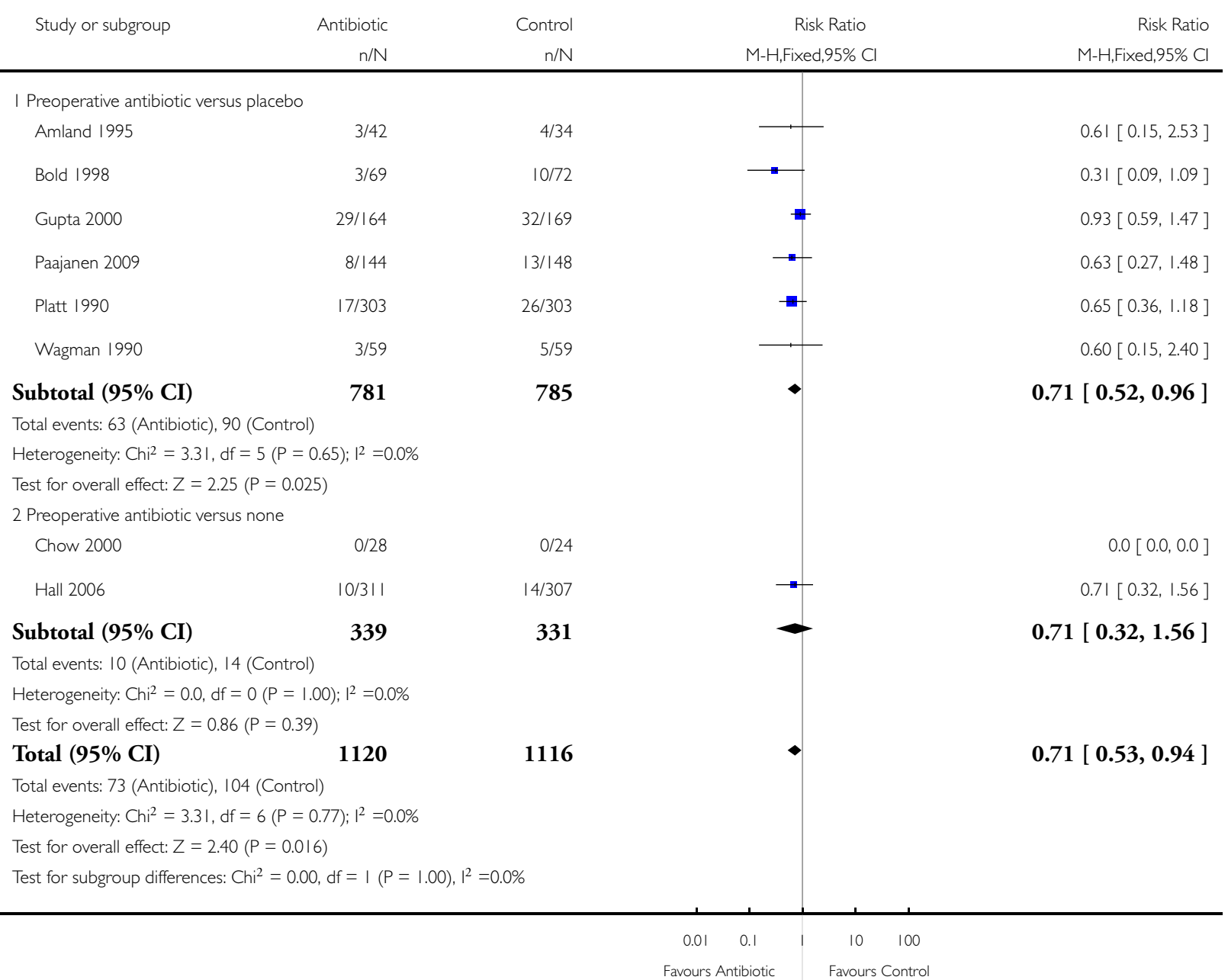


Analysis I.2. Comparison I Preoperative antibiotics versus none or placebo, Outcome 2 Wound infection cefonicid.

Review: Prophylactic antibiotics to prevent surgical site infection after breast cancer surgery

Comparison: I Preoperative antibiotics versus none or placebo

Outcome: 2 Wound infection cefonicid

\begin{tabular}{|c|c|c|c|c|c|}
\hline Study or subgroup & Cefonicid & Control & & Weight & Risk Ratio \\
\hline & $\mathrm{n} / \mathrm{N}$ & $\mathrm{n} / \mathrm{N}$ & M-H,Fixed,95\% Cl & & M-H,Fixed,95\% Cl \\
\hline Bold 1998 & $3 / 69$ & $10 / 72$ & 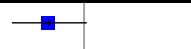 & $27.3 \%$ & $0.31[0.09,1.09]$ \\
\hline Platt 1990 & $17 / 303$ & $26 / 303$ & & $72.7 \%$ & $0.65[0.36,1.18]$ \\
\hline
\end{tabular}

Total $(95 \%$ CI $)$

372

375

$100.0 \%$

$0.56[0.33,0.95]$

Total events: 20 (Cefonicid), 36 (Control)

Heterogeneity: $\mathrm{Chi}^{2}=1.10, \mathrm{df}=1(\mathrm{P}=0.29) ; \mathrm{I}^{2}=9 \%$

Test for overall effect: $Z=2.15(P=0.032)$

Test for subgroup differences: Not applicable

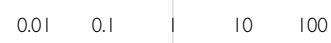

Favours cefonicid Favours control

Analysis I.3. Comparison I Preoperative antibiotics versus none or placebo, Outcome 3 Infection rates in those who received neo-adjuvant chemo.

Review: Prophylactic antibiotics to prevent surgical site infection after breast cancer surgery

Comparison: I Preoperative antibiotics versus none or placebo

Outcome: 3 Infection rates in those who received neo-adjuvant chemo

\begin{tabular}{|c|c|c|c|c|c|}
\hline \multirow[t]{2}{*}{ Study or subgroup } & Antibiotic & Placebo & Risk Ratio & Weight & Risk Ratio \\
\hline & $n / N$ & $\mathrm{n} / \mathrm{N}$ & M-H,Fixed,95\% Cl & & M-H,Fixed,95\% Cl \\
\hline Bold 1998 & $0 / 23$ & $2 / 24$ & 1 & $100.0 \%$ & $0.21[0.01,4.12]$ \\
\hline
\end{tabular}

Total (95\% CI)

23

24

$100.0 \%$

$0.21[0.01,4.12]$

Total events: 0 (Antibiotic), 2 (Placebo)

Heterogeneity: not applicable

Test for overall effect: $Z=1.03(P=0.30)$

Test for subgroup differences: Not applicable

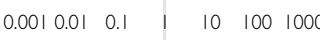

Favours treatment Favours control 
Analysis I.4. Comparison I Preoperative antibiotics versus none or placebo, Outcome 4 Cost of care. Cost of care

\begin{tabular}{ll|ll}
\hline Study & Antibiotic & Placebo & Cost calculation \\
\hline Bold 1998 & $\begin{array}{l}\text { Total cost in the treatment group: } \\
\text { USD 4382.57 } \\
\text { Average per patient: USD 49.80 }\end{array}$ & $\begin{array}{l}\text { Total cost in the placebo group: USD } \\
32,838.16 \\
\text { Average per patient: USD 364.87 }\end{array}$ & $\begin{array}{l}\text { Treatment costs were calculated from: } \\
\text { cost of prophylaxis administration, } \\
\text { charges for outpatient treatment and } \\
\text { charges for inpatient treatment }\end{array}$ \\
\hline
\end{tabular}

Analysis I.5. Comparison I Preoperative antibiotics versus none or placebo, Outcome 5 Adverse effects from antibiotics.

Adverse effects from antibiotics

\begin{tabular}{|c|c|c|}
\hline Study & Antibiotic & Control \\
\hline \multicolumn{3}{|c|}{ Preoperative antibiotics versus placebo } \\
\hline Amland 1995 & $\begin{array}{l}\text { Side effects considered by the investigator to be related to } \\
\text { treatment were recorded in } 4 \text { of the } 171 \text { patients receiving } \\
\text { the antibiotic }(2.3 \%) \\
2 \text { GI; } 1 \text { skin rash; } 1 \text { other }\end{array}$ & $\begin{array}{l}\text { Side effects considered by the investigator to be related } \\
\text { to treatment were present in } 5 \text { of the control group ( } 3 \text {. } \\
0 \% \text { ) } \\
2 \text { GI; } 2 \text { skin rash; } 1 \text { other }\end{array}$ \\
\hline Bold 1998 & $\begin{array}{l}\text { Stated as: "no patient suffered a complication related to } \\
\text { the antibiotic administration" }\end{array}$ & None recorded \\
\hline Gupta 2000 & $\begin{array}{l}41 \text { adverse events noted, details not provided as to } \\
\text { whether these were per patient or per event }\end{array}$ & $\begin{array}{l}33 \text { adverse events noted, details not provided as to } \\
\text { whether these were per patient or per event }\end{array}$ \\
\hline Paajanen 2009 & None recorded & None recorded \\
\hline Platt 1990 & None recorded & None recorded \\
\hline Wagman 1990 & Stated as: "no untoward reactions" & Stated as: "no untoward reactions" \\
\hline \multicolumn{3}{|c|}{ Preoperative antibiotics versus none } \\
\hline Chow 2000 & No adverse events recorded & No adverse events recorded \\
\hline Hall 2006 & Stated as 'no side effects observed' from the flucloxacillin & None stated \\
\hline
\end{tabular}


Analysis I.6. Comparison I Preoperative antibiotics versus none or placebo, Outcome 6 Time to onset of infection.

Time to onset of infection

\begin{tabular}{lll}
\hline Study & Antibiotic & Control \\
\hline Preoperative antibiotic versus placebo & \\
\hline Gupta 2000 & Mean time to onset of infection 12 days & Mean time to onset of infection 11 days \\
\hline Platt 1990 & Mean time to onset of infection 11 days & Mean time to onset of infection 10 days \\
\hline Wagman 1990 & Mean time to onset of infection 17.7 days & \\
\hline
\end{tabular}

Analysis I.7. Comparison I Preoperative antibiotics versus none or placebo, Outcome 7 Readmission to hospital.

Review: Prophylactic antibiotics to prevent surgical site infection after breast cancer surgery

Comparison: I Preoperative antibiotics versus none or placebo

Outcome: 7 Readmission to hospital

\begin{tabular}{|c|c|c|c|c|c|}
\hline Study or subgroup & $\begin{array}{r}\text { Antibiotic } \\
n / N\end{array}$ & $\begin{array}{l}\text { Control } \\
n / N\end{array}$ & $\begin{array}{c}\text { Risk Ratio } \\
\text { M- } \\
\text { H,Random,95\% } \\
\text { Cl }\end{array}$ & Weight & $\begin{array}{c}\text { Risk Ratio } \\
\text { M- } \\
\text { H,Random,95\% } \\
\text { Cl }\end{array}$ \\
\hline \multicolumn{6}{|c|}{ I Preoperative antibiotics versus placebo } \\
\hline Bold 1998 & $1 / 88$ & $9 / 90$ & + & $43.2 \%$ & $0.11[0.01,0.88]$ \\
\hline Platt 1990 & $5 / 303$ & $5 / 303$ & & $56.8 \%$ & $1.00[0.29,3.42]$ \\
\hline Subtotal $(95 \% \mathrm{CI})$ & 391 & 393 & & $100.0 \%$ & $0.39[0.04,3.49]$ \\
\hline \multicolumn{6}{|c|}{ Total events: 6 (Antibiotic), 14 (Control) } \\
\hline \multicolumn{6}{|c|}{ Heterogeneity: $\mathrm{Tau}^{2}=1.80 ; \mathrm{Chi}^{2}=3.43, \mathrm{df}=\mathrm{I}(\mathrm{P}=0.06) ; \mathrm{I}^{2}=71 \%$} \\
\hline \multicolumn{6}{|c|}{ Test for overall effect: $Z=0.84(P=0.40)$} \\
\hline
\end{tabular}


Analysis 2.1. Comparison 2 Perioperative antibiotics compared with no antibiotic, Outcome I Wound infection.

Review: Prophylactic antibiotics to prevent surgical site infection after breast cancer surgery

Comparison: 2 Perioperative antibiotics compared with no antibiotic

Outcome: I Wound infection

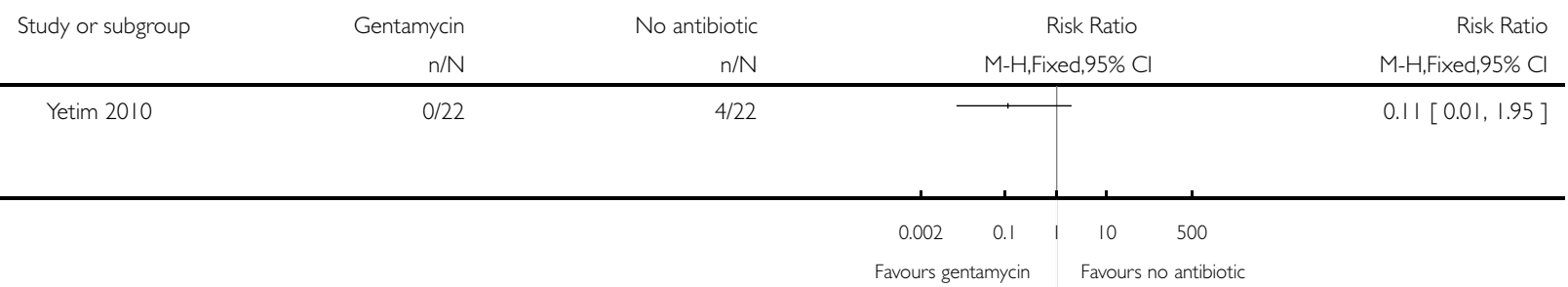

\section{AP PENDICES}

\section{Appendix I. Search strategy for the original version of this review}

We searched for published and unpublished trials using the following electronic databases:

- Cochrane Central Register of Controlled Trials (CENTRAL) (Issue 1, 2006)

- Cochrane Wounds Group Specialised Register (February 2006)

- Cochrane Breast Cancer Group Specialised Register (March 2005)

- MEDLINE 2002 to 2004 (earlier years were searched via CENTRAL)

- EMBASE 1980 to 2004 (earlier years were searched via CENTRAL)

- CINAHL 1982 to 2004

- NRR Issue 1, 2005

- SIGLE 1976 to 2004

The search strategy used to search The Cochrane Library Issue 1, 2006 is outlined below. This search strategy was used for searching all databases, however, it was amended to meet the specific requirements of each search interface.

1. BREAST CANCER explode all trees $(\mathrm{MeSH})$

2. (breast near cancer*)

3. (breast near neoplasm*)

4. (breast near carcinoma*)

5. (\#1 or \#2 or \#3 or \#4)

6. PREOPERATIVE CARE single term $(\mathrm{MeSH})$

7. PERIOPERATIVE CARE explode all trees (MeSH)

8. POSTOPERATIVE CARE explode all trees $(\mathrm{MeSH})$

9. POSTOPERATIVE COMPLICATIONS explode tree $1(\mathrm{MeSH})$

10. SURGICAL WOUND INFECTION single term $(\mathrm{MeSH})$

11. (surger* or surgical or operation*)

12. (operating next room*)

13. (operating next theater*) ${ }^{* *}$ note American spelling

14. ((pre next operative) or preoperative)

15. ((peri next operative) or perioperative)

16. ((post next operative) or postoperative)

17. MAMMAPLASTY explode tree $1(\mathrm{MeSH})$

Prophylactic antibiotics to prevent surgical site infection after breast cancer surgery (Review)

Copyright (C) 2012 The Cochrane Collaboration. Published by John Wiley \& Sons, Ltd. 
18. BREAST IMPLANTATION single term $(\mathrm{MeSH})$

19. (breast next implants)

20. (breast near implant*)

21. (breast near augmentation*)

22. (silicone near implant*)

23. (saline near implant*)

24. (breast near reconstruction*)

25. mastectomy

26. (\#6 or $\# 7$ or $\# 8$ or $\# 9$ or $\# 10$ or $\# 11$ or $\# 12$ or \#13 or \#14 or \#15 or \#16 or \#17 or \#18 or \#19 or \#20 or \#21 or \#22 or \#23 or \# 24 or \#25)

27. ANTI-BACTERIAL AGENTS explode tree $1(\mathrm{MeSH})$

28. antibiotic*

29. ((anti next bacterial*) or antibacterial $\left.{ }^{*}\right)$

30. ((anti next microbial $\left.{ }^{*}\right)$ or antimicrobial $\left.{ }^{*}\right)$

31. (anti next infect*)

32. clindamycin

33. (cefuroxime or cefuroxim)

34. ceftazidime

35. ofloxacin

36. levofloxacin

37. azithromycin

38. sulbactam

39. ampicillin

40. mezlocillin

41. oxacillin

42. vancomycin

43. tobramycin

44. ciprofloxacin

45. (\#27 or \#28 or \#29 or \#30 or \#31 or \#32 or \#33 or \#34 or \#35 or \#36 or \#37 or \#38 or \#39 or \#40 or \#41 or \#42 or \#43 or \#44)

46. (\#5 and \#26 and \#45)

\section{Appendix 2. Ovid MEDLINE search strategy}

1 exp Surgical Wound Infection/

2 (surg\$ adj5 infection\$).mp.

3 (surgical adj5 wound\$).mp.

4 ((postoperative or post-operative) adj5 infection\$).mp.

5 exp Preoperative Care/

6 ((preoperative or pre-operative) adj care).mp.

7 exp Perioperative Care/

8 ((perioperative or peri-operative) adj care).mp.

9 or $/ 1-8$

10 Breast Neoplasms/su [Surgery]

11 (breast cancer\$ adj5 surg\$).mp.

12 (breast neoplasm\$ adj5 surg\$).mp.

13 (breast carcinoma $\$$ adj5 surg\$).mp.

14 exp Mastectomy/

15 exp Mammaplasty/

16 (mastectomy or mammaplasty).mp.

17 exp Breast/su [Surgery]

18 or/10-17

199 and 18

Prophylactic antibiotics to prevent surgical site infection after breast cancer surgery (Review)

Copyright $\odot 2012$ The Cochrane Collaboration. Published by John Wiley \& Sons, Ltd. 
21 (antibiotic\$ or clindamycin or cefuroxime or cefuroxim or ceftazidime or ofloxacin or levofloxacin or azithromycin or sulbactam or ampicillin or mezlocillin or oxacillin or vancomycin or tobramycin or ciprofloxacin).mp.

22 or $/ 20-21$

$23 \quad 19$ and 22

\section{Appendix 3. Ovid EMBASE search strategy}

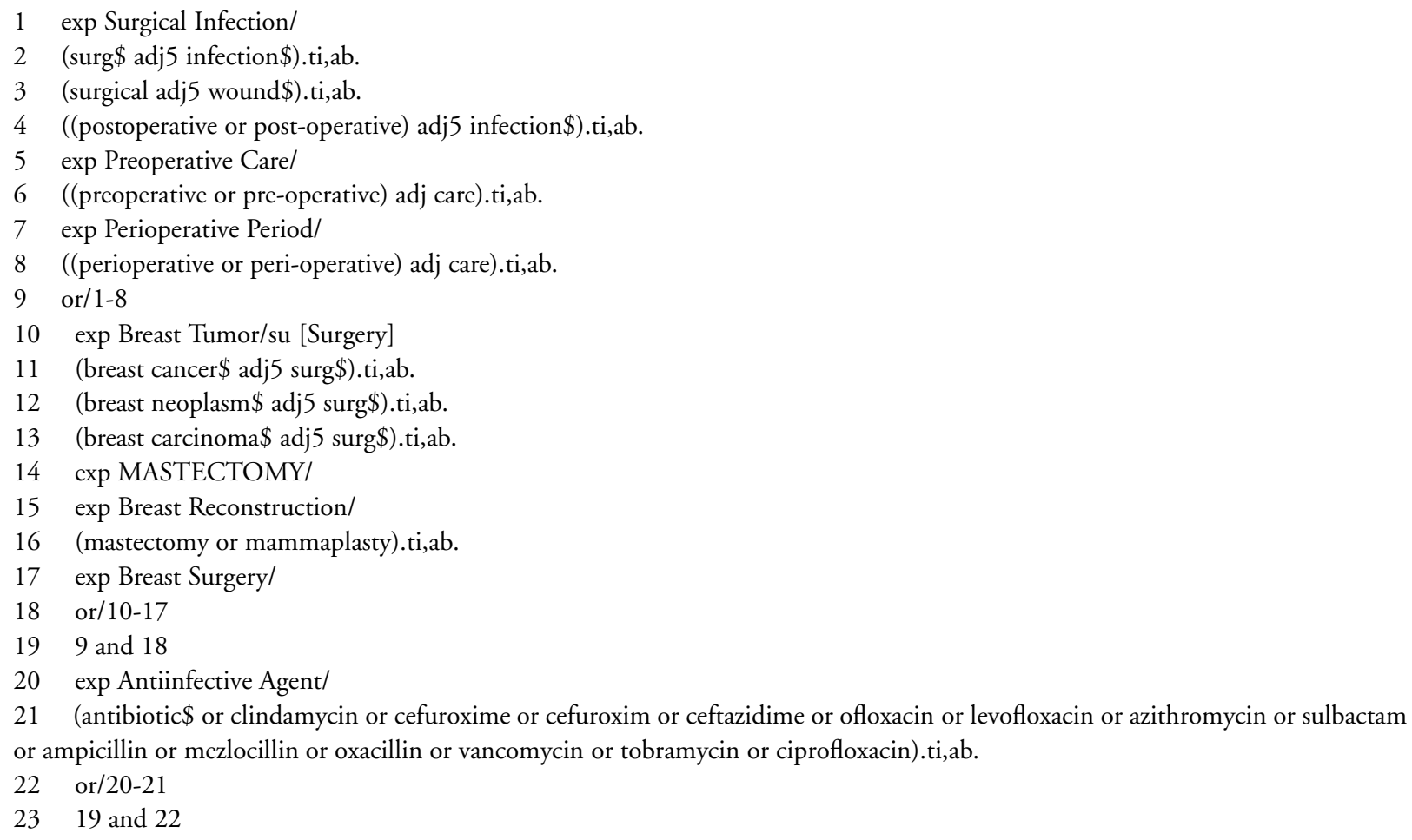

\section{Appendix 4. EBSCO CINAHL search strategy}

S23 S11 and S19 and S22

S22 S20 or S21

S21 TI ( antibiotic* or clindamycin or cefuroxime or cefuroxim or ceftazidime or ofloxacin or levofloxacin or azithromycin orsulbactam or ampicillin or mezlocillin or oxacillin or vancomycin or tobramycin or ciprofloxacin) or AB ( antibiotic* or clindamycin or cefuroxime or cefuroxim or ceftazidime or ofloxacin or levofloxacin or azithromycin orsulbactam or ampicillin or mezlocillin or oxacillin or vancomycin or tobramycin or ciprofloxacin )

S20 (MH "Antibiotics+")

S19 S12 or S13 or S14 or S15 or S16 or S17 or S18

S18 (MH "Breast/SU")

S17 TI ( mastectomy or mammaplasty) or AB ( mastectomy or mammaplasty )

S16 (MH "Mastectomy+")

S15 TI breast carcinoma* N5 surg* or AB breast carcinoma* N5 surg*

S14 TI breast neoplasm* N5 surg* or AB breast neoplasm* N5 surg*

S13 TI breast cancer* N5 surg* or AB breast cancer* N5 surg*

S12 (MH "Breast Neoplasms/SU")

S11 S1 or S2 or S3 or S4 or S5 or S6 or S7 or S8 or S9 or S10

S10 TI ( perioperative care or peri-operative care ) or AB ( perioperative care or peri-operative care ) 
S9 (MH "Perioperative Care+")

S8 TI ( preoperative care or pre-operative care ) or $\mathrm{AB}$ ( preoperative care or pre-operative care )

S7 (MH "Preoperative Care+")

S6 TI ( postoperative* N5 infection* OR post-operative* N5 infection*) or AB ( postoperative* N5 infection* OR post-operative* N5 infection* $^{*}$ )

S5 TI wound* N5 infection* or AB wound* N5 infection*

S4 TI surg* N5 wound* or AB surg* N5 wound*

S3 TI surg* N5 infection* or AB surg* N5 infection*

S2 (MH "Surgical Wound Dehiscence")

S1 (MH "Surgical Wound Infection")

\section{Appendix 5. Risk of bias criteria}

\section{Was the allocation sequence randomly generated?}

\section{Low risk of bias}

The investigators describe a random component in the sequence generation process such as: referring to a random number table; using a computer random number generator; coin tossing; shuffling cards or envelopes; throwing dice; drawing of lots.

\section{High risk of bias}

The investigators describe a non-random component in the sequence generation process. Usually, the description would involve some systematic, non-random approach, for example: sequence generated by odd or even date of birth; sequence generated by some rule based on date (or day) of admission; sequence generated by some rule based on hospital or clinic record number.

\section{Unclear}

Insufficient information about the sequence generation process to permit judgement of low or high risk of bias.

\section{Was the treatment allocation adequately concealed?}

\section{Low risk of bias}

Participants and investigators enrolling participants could not foresee assignment because one of the following, or an equivalent method, was used to conceal allocation: central allocation (including telephone, web-based and pharmacy-controlled randomisation); sequentially-numbered drug containers of identical appearance; sequentially-numbered, opaque, sealed envelopes.

\section{High risk of bias}

Participants or investigators enrolling participants could possibly foresee assignments and thus introduce selection bias, such as allocation based on: using an open random allocation schedule (e.g. a list of random numbers); assignment envelopes were used without appropriate safeguards (e.g. if envelopes were unsealed or non opaque or not sequentially numbered); alternation or rotation; date of birth; case record number; any other explicitly unconcealed procedure.

\section{Unclear}

Insufficient information to permit judgement of low or high risk of bias. This is usually the case if the method of concealment is not described or not described in sufficient detail to allow a definite judgement, for example if the use of assignment envelopes is described, but it remains unclear whether envelopes were sequentially numbered, opaque and sealed. 


\section{Blinding - was knowledge of the allocated interventions adequately prevented during the study?}

\section{Low risk of bias}

Any one of the following.

- No blinding, but the review authors judge that the outcome and the outcome measurement are not likely to be influenced by lack of blinding.

- Blinding of participants and key study personnel ensured, and unlikely that the blinding could have been broken.

- Either participants or some key study personnel were not blinded, but outcome assessment was blinded and the non-blinding of others unlikely to introduce bias.

\section{High risk of bias}

Any one of the following.

- No blinding or incomplete blinding, and the outcome or outcome measurement is likely to be influenced by lack of blinding.

- Blinding of key study participants and personnel attempted, but likely that the blinding could have been broken.

- Either participants or some key study personnel were not blinded, and the non-blinding of others likely to introduce bias.

\section{Unclear}

Any one of the following.

- Insufficient information to permit judgement of low or high risk of bias.

- The study did not address this outcome.

\section{Were incomplete outcome data adequately addressed?}

\section{Low risk of bias}

Any one of the following.

- No missing outcome data.

- Reasons for missing outcome data unlikely to be related to true outcome (for survival data, censoring unlikely to be introducing bias).

- Missing outcome data balanced in numbers across intervention groups, with similar reasons for missing data across groups.

- For dichotomous outcome data, the proportion of missing outcomes compared with observed event risk not enough to have a clinically relevant impact on the intervention effect estimate.

- For continuous outcome data, plausible effect size (difference in means or standardised difference in means) among missing outcomes not enough to have a clinically relevant impact on observed effect size.

- Missing data have been imputed using appropriate methods.

\section{High risk of bias}

Any one of the following.

- Reason for missing outcome data likely to be related to true outcome, with either imbalance in numbers or reasons for missing data across intervention groups.

- For dichotomous outcome data, the proportion of missing outcomes compared with observed event risk enough to induce clinically relevant bias in intervention effect estimate.

- For continuous outcome data, plausible effect size (difference in means or standardised difference in means) among missing outcomes enough to induce clinically relevant bias in observed effect size.

- 'As-treated' analysis done with substantial departure of the intervention received from that assigned at randomisation.

- Potentially inappropriate application of simple imputation. 


\section{Unclear}

Any one of the following.

- Insufficient reporting of attrition/exclusions to permit judgement of low or high risk of bias (e.g. number randomised not stated, no reasons for missing data provided).

- The study did not address this outcome.

\section{Are reports of the study free of suggestion of selective outcome reporting?}

\section{Low risk of bias}

Any of the following.

- The study protocol is available and all of the study's pre-specified (primary and secondary) outcomes that are of interest in the review have been reported in the pre-specified way.

- The study protocol is not available but it is clear that the published reports include all expected outcomes, including those that were pre-specified (convincing text of this nature may be uncommon)

\section{High risk of bias}

Any one of the following.

- Not all of the study's pre-specified primary outcomes have been reported.

- One or more primary outcomes is reported using measurements, analysis methods or subsets of the data (e.g. subscales) that were not pre-specified.

- One or more reported primary outcomes were not pre-specified (unless clear justification for their reporting is provided, such as an unexpected adverse effect).

- One or more outcomes of interest in the review are reported incompletely so that they cannot be entered in a meta-analysis.

- The study report fails to include results for a key outcome that would be expected to have been reported for such a study.

\section{Unclear}

Insufficient information to permit judgement of low or high risk of bias. It is likely that the majority of studies will fall into this category.

\section{Other sources of potential bias}

\section{Low risk of bias}

The study appears to be free of other sources of bias.

\section{High risk of bias}

There is at least one important risk of bias. For example, the study:

- had a potential source of bias related to the specific study design used; or

- had extreme baseline imbalance; or

- has been claimed to have been fraudulent; or

- had some other problem.

\section{Unclear}

There may be a risk of bias, but there is either:

- insufficient information to assess whether an important risk of bias exists; or

- insufficient rationale or evidence that an identified problem will introduce bias. 


\section{WHAT'S NEW}

Last assessed as up-to-date: 31 August 2011.

\begin{tabular}{lll}
\hline Date & Event & Description \\
\hline 23 September 2011 & $\begin{array}{l}\text { New citation required but conclusions have not } \\
\text { changed }\end{array}$ & New authors added to the review \\
\hline 31 August 2011 & New search has been performed & $\begin{array}{l}\text { Second update, new searches, two studies added } \\
\text { (Paajanen 2009; Yetim 2010), two studies excluded } \\
\text { (Esposito 2006; Sanguinetti 2009). }\end{array}$ \\
\hline
\end{tabular}

\section{H I S T O R Y}

Protocol first published: Issue 2, 2005

Review first published: Issue 2, 2006

\begin{tabular}{lll}
\hline Date & Event & Description \\
\hline 11 August 2009 & Amended & Contact details updated. \\
\hline 24 October 2008 & New search has been performed & One new trial added. Conclusions unchanged. \\
\hline 28 July 2008 & Amended & Converted to new review format. \\
\hline 18 December 2005 & New citation required and conclusions have changed & Substantive amendment \\
\hline
\end{tabular}

\section{CONTRIBUTIONSOFAUTHORS}

Frances Bunn: provided methodological support, screened records, extracted data, helped to write the review and undertook the updating of the review.

Daniel Jones: contributed to the second update of this review, screened records for eligibility, extracted data, undertook the risk of bias assessment and added text to the review update.

Sophie Bell-Syer: contributed to the second update of this review, screened records for eligibility, extracted data, undertook the risk of bias assessment and commented on the review update.

\section{Contributions of editorial base:}

Nicky Cullum: edited the review, advised on methodology, interpretation and review content. Approved the final review and review update prior to submission.

Sally Bell-Syer: co-ordinated the editorial process. Advised on methodology, interpretation and content. Edited and copy edited the review. Screened studies for the updated review and edited the updated review.

Ruth Foxlee: designed the search strategy and edited the search methods section for the update. 


\section{DECLARATIONS OF INTEREST}

None known.

\section{SOURCES OF SUPPORT}

\section{Internal sources}

- University of Hertfordshire, UK.

- Department of Health Sciences, University of York, York, UK.

\section{External sources}

- NIHR/Department of Health (England), (Cochrane Wounds Group), UK.

\section{NDEX TERMS}

\section{Medical Subject Headings (MeSH)}

*Antibiotic Prophylaxis; Breast Neoplasms [*surgery]; Randomized Controlled Trials as Topic; Surgical Wound Infection [* prevention $\&$ control]

\section{MeSH check words}

Female; Humans 